\title{
Microalbuminuria, blood pressure and diabetic renal disease: origin and development of ideas
}

\section{C.E. Mogensen}

Medical Department M, Diabetes and Endocrinology, Aarhus Kommunehospital, Aarhus University Hospital, Aarhus, Denmark

Keywords Type I diabetes, Type II diabetes, hyperfiltration, microalbuminuria, proteinuria, diabetic nephropathy, dextran clearance, exercise, diabetic nephropathy, antihypertensive treatment, angiotensin converting enzyme inhibition, risk factors for nephropathy, hyperglycaemia, blood pressure, hypertension, metabolic syndrome, glycaemic control, meta-analysis.

\section{Introduction}

Microalbuminuria and diabetic renal disease are closely linked [1-14] and are associated with hypertension and often antecedent hyperfiltration [1]. Microalbuminuria usually indicates the beginning of diabetic nephropathy as opposed to overt nephropathy characterized by clinical proteinuria according to generally defined standards [14-15] but it has an even broader impact because it is also often found in essential hypertension as first described by Parving et al. [16]. This indicates that it is involved in early renal and vascular disorders which can predict advancing renal disease as well as the progression of cardiovascular disease [17]. This concept of prediction however is becoming increasingly difficult to pursue because many patients are treated with anti-hypertensive drugs and other types of interventions when microalbuminuria is diagnosed; such measures often return albumin excretion to normal [17-19]. Further in

Corresponding author: C. E. Mogensen, Medical Department M, Diabetes and Endocrinology, Aarhus Kommunehospital, Aarhus University Hospital, DK-8000 Aarhus, Denmark.

Abbreviations: GFR, Glomular filtration rate; ACE, angiotensin-converting enzyme.

29th Claude Bernard Lecture given during the 33rd Annual Meeting of the EASD, Helsinki, July 1997 population-based studies microalbuminuria is not uncommon, especially in elderly people where it is also strongly related to cardiovascular disease and mortality, as in both in Type I (insulin-dependent) and Type II (non-insulin-dependent) diabetes mellitus [20-29]. Whether it should be considered as a part of the metabolic syndrome is still doubtful as it relates more specifically to high blood pressure and glucose intolerance [30]. In diabetic pregnancy, an increase of microalbuminuria predicts complications $[7,31]$.

Thus microalbuminuria can be considered as an early sign of damage not only of the kidney but also the cardiovascular system [17, 18, 28, 32]. For intervention strategies to prevent or reverse the abnormality, also in terms of hard end-points, it is crucial to define and recognize pathogenetic risk factors involved in the aetiology of disease [33-41]. It is, however, equally important to consider early signs of disease because microalbuminuria usually indicates detectable renal structural damage [42-49]. If we can diagnose and intervene with effective strategies at an earlier stage, e. g. by hyperfiltration [50-56] or guided by provocation tests $[57,58]$ or with very early risk factors we might be able to further improve prognosis. Very early risk factors to be considered could be pre-natal, such as genetic elements, birth-weight and familial predisposition to renal and vascular disease.

The interrelation of risk factors seems to some extent, however, to have confused the medical community for years. This also applies to the real pathogenetic importance of hyperglycaemia per se, not only because of poor recognition of hyperglycaemia before the $\mathrm{HbA}_{1 \mathrm{C}}-\mathrm{era}$, but also the failure to recognize that the two important risk factors, high blood pressure and increased blood glucose concentrations, must be considered together. These are fundamental risk factors for cardiovascular disease also, and in diabetes, hyperlipidaemia could be of equal or even greater importance [59]. Considered together, the 
Table 1. Studies related to nephromegaly, hyperfiltration and microalbuminuria

\begin{tabular}{|c|c|c|c|c|}
\hline Phenomenon & Nephromegaly & Hyperfiltration & $\begin{array}{l}\text { Immune measurement } \\
\text { of albumin }\end{array}$ & $\begin{array}{l}\text { Microalbuminuria } \\
\text { Type I diabetes }\end{array}$ \\
\hline Early observation & $\begin{array}{l}\text { Paris } 1849 \\
\text { C. Bernard [62] }\end{array}$ & $\begin{array}{l}\text { Belgium/Italy } \\
\text { Switzerland [276-278] }\end{array}$ & Sweden [99] & $\begin{array}{l}\text { London, Aarhus } \\
{[100,283,284]}\end{array}$ \\
\hline $\begin{array}{l}\text { Subsequent studies } \\
\text { and observations }\end{array}$ & Several pathologists [63] & Denmark $[279,280]$ & London, RIA [282] & $\begin{array}{l}\text { Follow-up: } \\
\text { London, Copenhagen } \\
\text { Aarhus }[73,105,106]\end{array}$ \\
\hline $\begin{array}{l}\text { Confirmed and/or } \\
\text { clinical significant }\end{array}$ & Munich 1998 [69] & $\begin{array}{l}\text { Confirmed but } \\
\text { clinical assessment } \\
\text { too cumbersome }\end{array}$ & $\begin{array}{l}\text { Rapid procedures } \\
\text { Aarhus [102-104], } \\
\text { Guidelines [285-287] }\end{array}$ & $\begin{array}{l}\text { Several guidelines } \\
{[287,288,291]}\end{array}$ \\
\hline
\end{tabular}

Table 2. Glomerulopathy, epidemiology, syndrome $\mathrm{X}$ and significance of near normal glycaemia

\begin{tabular}{|c|c|c|c|c|}
\hline Phenomenon & $\begin{array}{l}\text { Glomerulopathy } \\
\text { and proteinuria }\end{array}$ & $\begin{array}{l}\text { Epidemiology of micro- } \\
\text { albuminuria and mortality } \\
\text { (incl. Type II diabetes) }\end{array}$ & $\begin{array}{l}\text { Metabolic syndrome } \\
\text { or syndrome X }\end{array}$ & $\begin{array}{l}\text { Significance of } \\
\text { glycaemic control }\end{array}$ \\
\hline Early observation & $\begin{array}{l}\text { Kimmelstiel and Wilson, } \\
1936 \text { [292, 293] }\end{array}$ & $\begin{array}{l}\text { London, Epidemiology [100] } \\
\text { Aarhus, Mortality }[112,113]\end{array}$ & $\begin{array}{l}\text { Sweden } 1923[140] \\
\text { England } 1939[141] \\
\text { France } 1949[142,143] \\
\text { Italy } 1965[144]\end{array}$ & $\begin{array}{l}\text { Keiding } 1952[300] \\
\text { Providing the concept } \\
\text { Pirart } 1978[84]\end{array}$ \\
\hline Subsequent studies & $\begin{array}{l}\text { Several pathologists } \\
\text { [294-297] }\end{array}$ & $\begin{array}{l}\text { Aarhus [116] } \\
\text { Fredericia [20] } \\
\text { London [27] }\end{array}$ & $\begin{array}{l}\text { Ferranini [32] } \\
\text { Reaven [299] } \\
\text { Hoorn Study [30] }\end{array}$ & $\begin{array}{l}\text { Scandinavia [301] } \\
\text { Gothenburg [222] }\end{array}$ \\
\hline Newer studies & $\begin{array}{l}\text { Aarhus/Minneapolis } \\
\text { (Morphometry) [47, 298] } \\
\text { Japan [127] }\end{array}$ & $\begin{array}{l}\text { Mortality data firmly } \\
\text { confirmed [113] }\end{array}$ & $\begin{array}{l}\text { Concept used by many } \\
\text { investigators }\end{array}$ & $\begin{array}{l}\text { DCCT [41] } \\
\text { Oslo/Aarhus [48] } \\
\text { Gothenburg [302] } \\
\text { Copenhagen [15] }\end{array}$ \\
\hline $\begin{array}{l}\text { Confirmed and/or } \\
\text { clinical significant }\end{array}$ & $\begin{array}{l}\text { Several reviews } \\
{[147,291]}\end{array}$ & $\begin{array}{l}\text { Used now in all epidemiol- } \\
\text { ogical and large trials }\end{array}$ & $\begin{array}{l}\text { Still ill defined [145] } \\
\text { Not measured clinically }\end{array}$ & $\begin{array}{l}\text { Several guidelines } \\
\text { (widely accepted) }\end{array}$ \\
\hline
\end{tabular}

long-term occurrence over the years of high blood glucose and high blood pressure is highly indicative of the development of renal disease, other microvascular lesions and also macrovascular disease. Conversely, low blood pressure can be protective, even with long-standing diabetes and poor glycaemic control. Another confounding issue has been the seemingly independent development of retinopathy and renal disease in some situations. Some studies have failed to recognize that morphological diagnosis of renal disease is often lacking in epidemiological studies, by contrast to retinopathy, although clinically meaningful microvascular disease usually develops in a very concordant fashion $[60,61]$.

This review discusses how pertinent concepts of diabetic renal disease have developed over the years (Tables 1-4). It also focuses on earlier diagnosis based on exact measures such as ambulatory blood pressure, provocation test and precise monitoring of glomular filtration rate (GFR) as well as other renal function tests to define the earliest possible stage predictive of incipient or overt disease (Table 5). Several new theoretical concepts are mentioned briefly (Table 6) and potential end-points are discussed (Table 7).

\section{Nephromegaly and hyperfiltration}

The origin of ideas often goes much further back than investigators in the research field generally acknowledge. Thus, nephromegaly had been observed more than a century before it was rediscovered. C. Bernard [62], with quite another purpose in mind, observed pronounced nephromegaly in a patient with newly diagnosed diabetes who was in the care of M. Rayer in a Parisian Hospital in the 1840 s and was examined after a sudden and unexpected death. The nephromegaly seen in the post mortem examination corresponds closely with new observations (Fig. 1). Between 1848 and 1974 nephromegaly was not broadly recognized clinically, although it seemed to be a common finding among pathologists [63]. It was described in textbooks in France even before C. Bernard $[64,65]$. New observations indicated considerable renal enlargement in experimental diabetes [66]. Nephromegaly was proposed as an index of long-term glycaemic control and could thus theoretically be used to document a possible relation between hyperglycaemia and later overt nephropathy [67-68]. This concept was recently further elaborated by the 
Table 3. The concept of renoprotection

\begin{tabular}{|c|c|c|c|c|}
\hline Phenomenon & $\begin{array}{l}\text { Protection by AHT } \\
\text { Incipient nephropathy } \\
\text { (Type I) }\end{array}$ & $\begin{array}{l}\text { Protection by AHT } \\
\text { Overt nephropathy } \\
\text { (Type I) }\end{array}$ & $\begin{array}{l}\text { Protection by AHT } \\
\text { in Microalbuminuria } \\
\text { (Type II) }\end{array}$ & $\begin{array}{l}\text { ACE-I and renal } \\
\text { protection }\end{array}$ \\
\hline Early observation & Aarhus 1985 [190] & $\begin{array}{l}\text { Aarhus 1976-1982 } \\
{[208,211]}\end{array}$ & Israel [200, 201] & $\begin{array}{l}\text { Boston, experimental } \\
{[239,307]}\end{array}$ \\
\hline Subsequent observation & $\begin{array}{l}\text { Paris [195] } \\
\text { Copenhagen [196, 197] } \\
\text { Melbourne [198] }\end{array}$ & $\begin{array}{l}\text { Copenhagen [212-216] } \\
\text { Goethenburg [217] }\end{array}$ & $\begin{array}{l}\text { Melbourne [198] } \\
\text { Several studies }\end{array}$ & $\begin{array}{l}\text { Aarhus [308] } \\
\text { Paris [195] } \\
\text { Copenhagen [197] } \\
\text { Melbourne [198] }\end{array}$ \\
\hline $\begin{array}{l}\text { Confirmed and } \\
\text { clinical significant }\end{array}$ & Several guidelines [287] & Several guidelines [287] & $\begin{array}{l}\text { Clinically used [305] } \\
\text { Multifactorial inter- } \\
\text { vention important [306] }\end{array}$ & $\begin{array}{l}\text { Maybe more effective } \\
\text { than ordinary AHT [15] }\end{array}$ \\
\hline
\end{tabular}

AHT, antihypertensive treatment

Table 4. Pathophysiological and genetic studies

\begin{tabular}{|c|c|c|c|c|}
\hline Phenomenon & $\begin{array}{l}\text { Complication genetically or } \\
\text { metabolically determined }\end{array}$ & $\begin{array}{l}\text { Provocation tests } \\
\text { (e.g. exercise) }\end{array}$ & $24 \mathrm{~h}$-amb. BP in diabetes & $\begin{array}{l}\text { Dextran and PVP } \\
\text { clearance }\end{array}$ \\
\hline Early observation & Siperstein 1973 [82] & Karlefors [146] & Rubler, 1982 [160] & Uppsala [180] \\
\hline Newer studies & $\begin{array}{l}\text { London [309] } \\
\text { Boston [310] } \\
\text { Copenhagen [86] } \\
\text { France [311] }\end{array}$ & $\begin{array}{l}\text { Only few studies } \\
{[177,312,313]}\end{array}$ & Several studies [175] & $\begin{array}{l}\text { Copenhagen [183] } \\
\text { San Francisco [184] }\end{array}$ \\
\hline Clinical significance & $\begin{array}{l}\text { My present view: } \\
\text { Renal complication } \\
\text { mainly metabolically } \\
\text { determined and modulated } \\
\text { by hypertension }\end{array}$ & $\begin{array}{l}\text { Not widely used, but may } \\
\text { be relevant in treatment } \\
\text { trials }[177,314]\end{array}$ & $\begin{array}{l}\text { Should be used more } \\
\text { (Guidelines elaborated) } \\
{[175]}\end{array}$ & Little used [2] \\
\hline
\end{tabular}

PVP, polyvinyl-pyrrolidin

observation that diabetic patients with extreme nephromegaly were at greater risk of developing overt renal disease [69].

The functional abnormality, to some extent concomitant with nephromegaly, is hyperfiltration and intrarenal hypertension which have been originally proposed to be of key pathogenetic relevance by Brenner and this group [70]. Studies in diabetes indicate that hyperfiltration is of considerable importance [56] as evidenced by several follow-up studies, most convincingly by Rudberg et al. [71]. Some studies have failed to document correlations possibly because of too broad inclusion criteria, e.g. patients with newly diagnosed diabetes before insulin treatment [56]. These patients are known to have pronounced hyperfiltration that can be reversed with treatment [72]. The predictive role of hyperfiltration could be difficult to study now, because there is a more intensified control in diabetes, both before and after the development of microalbuminuria. Even so, hyperfiltration, associated with microalbuminuria and slightly raised blood pressure [73], is likely to be strongly predictive of renal disease, perhaps to some extent because hyperfiltration in parallel to nephromegaly is related to poor metabolic control [68, 74]. In contrast to microalbuminuria, hyperfiltration and nephromegaly are, however, rarely included in

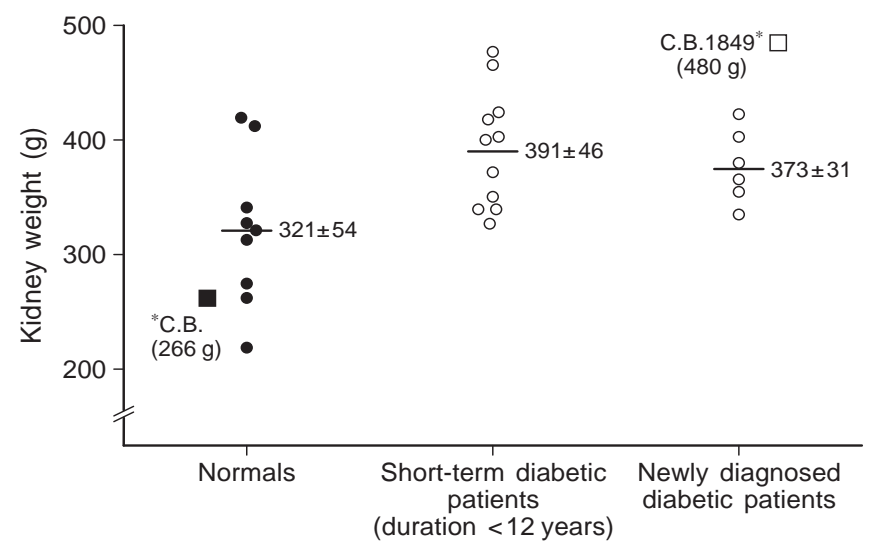

Fig. 1. Kidney weight in normal and diabetic subjects. *Reference $[62,67,68]$ 


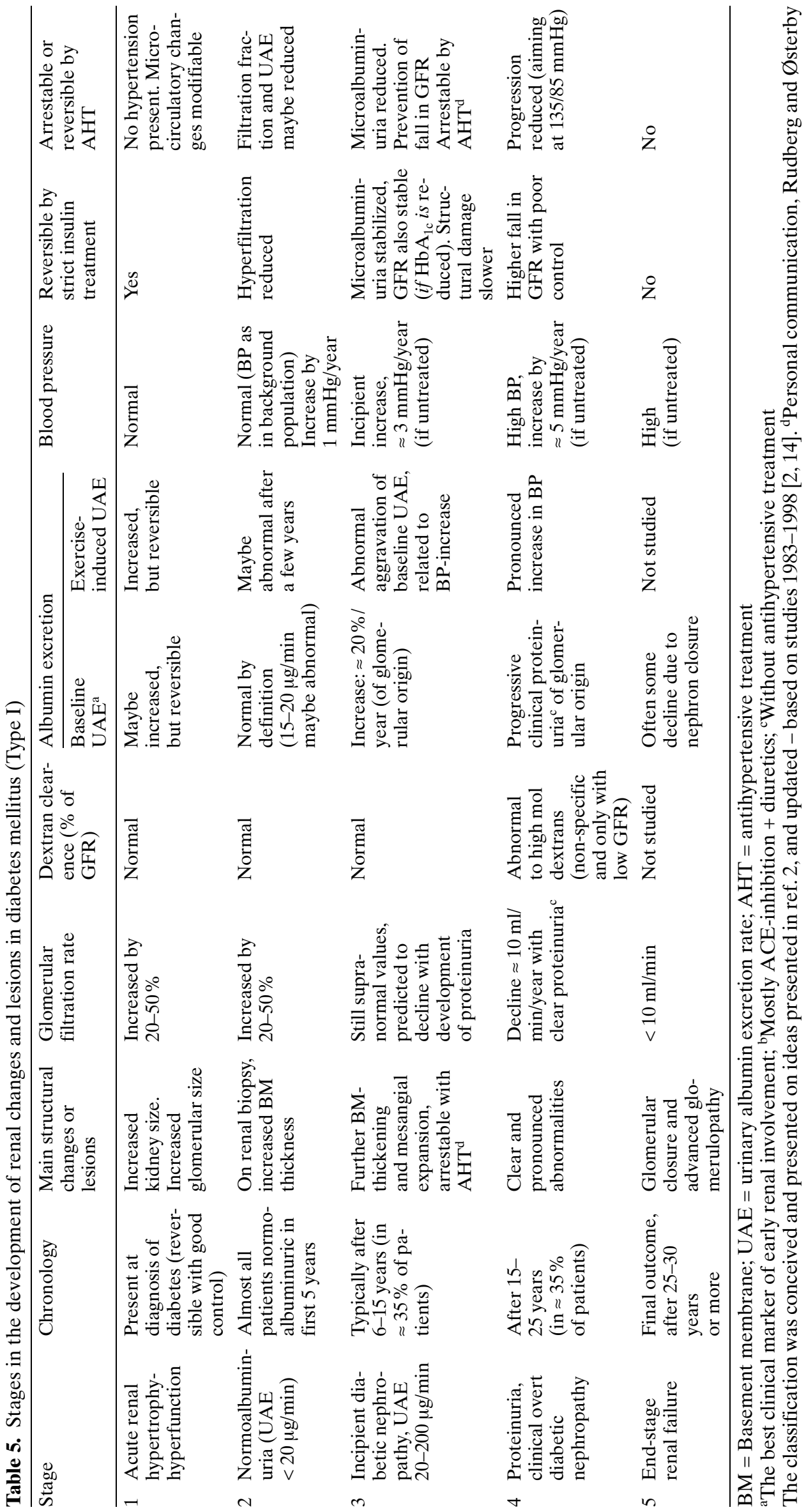


Table 6. Newer therapeutic concepts

\begin{tabular}{llllll}
\hline & $\begin{array}{l}\text { Aldose-reductose } \\
\text { inhibition }\end{array}$ & $\begin{array}{l}\text { Selective growth } \\
\text { factor inhibition }\end{array}$ & $\begin{array}{l}\text { Selective protein- } \\
\text { kinase-C inhibition }\end{array}$ & $\begin{array}{l}\text { Angiotensin } \\
\text { receptor blockade }\end{array}$ & AGE-inhibition \\
\hline $\begin{array}{l}\text { Theoretical, } \\
\text { basis, reference }\end{array}$ & Mau Pedersen [51] & $\begin{array}{l}\text { Flyvbjerg, Ziyadeh } \\
{[315,316]}\end{array}$ & Koya and King [317] & Hollenberg [318] & Cooper and Jerums \\
Human studies & Mau Pedersen [51, 52] & $\begin{array}{l}\text { Few, Mau Pedersen } \\
{[50]}\end{array}$ & In progress & $\begin{array}{l}\text { Many important } \\
\text { studies conducted and } \\
\text { in progress [247, 248] } \\
\text { Widely used }\end{array}$ \\
Clinically used & No & Not yet & No & Wo & No \\
\hline
\end{tabular}

Table 7. The endpoint: GFR-decline rate related to intermediary end points in diabetic patients

\begin{tabular}{|c|c|c|}
\hline Intermediary end points & GFR-decline (Young Type I diabetic patients) & $\begin{array}{l}\text { GFR-decline (Middle-aged Type II diabetic } \\
\text { patients) }\end{array}$ \\
\hline Microalbuminuria $^{\mathrm{a}}(20-200 \mu \mathrm{g} / \mathrm{min})$ & $\begin{array}{l}\text { Decline in } \mathrm{GFR}^{\mathrm{a}} \text { only seen with progression } \\
\text { to proteinuria }\end{array}$ & $\begin{array}{l}\text { Decline rate of GFR }{ }^{a} \text { usually not noteably } \\
\text { different from normoalbuminuria }\end{array}$ \\
\hline Blood pressure ${ }^{\mathrm{b}}$ & $\begin{array}{l}\text { Controversy exists but a clear risk factor } \\
\text { with co-existing abnormal albuminuria }\end{array}$ & $\begin{array}{l}\text { Controversy exists but a clear risk factor } \\
\text { with co-existing abnormal albuminuria }\end{array}$ \\
\hline
\end{tabular}

Related to future mortality and ESRD with increasing power $\left(^{a}\right)\left(^{b}\right)\left(^{c}\right)$.

ESRD, end-stage renal disease

the clinical evaluation of patients, partly because their relevance under routine circumstances can be difficult to ascertain as the procedures involved are technically too demanding in a busy clinic. Regarding mechanisms, atrial natriuretic peptide could be involved both in hyperfiltration [74] and microalbuminuria $[75,76]$. The genesis of hyperfiltration is, however, likely to be multifactorial [77].

\section{Genetic or familial factors}

It has been suggested that there is a discrepancy between the development of renal disease and retinopathy in that retinopathy is much more common than nephropathy. It has possibly not been taken into consideration that the diagnoses of retinopathy is most often based on retinal photographs, that is morphology. By contrast renal disease is diagnosed by the occurrence of microalbuminuria or proteinuria and only rarely through renal biopsies. With morphological diagnosis the prevalence of the two microvascular lesions could be very similar. Actually, as shown by the Melbourne group, development of clinically important renal disease is strongly associated with the occurrence of retinopathy [60,61]. Thus, the basis for considering susceptibility factors distinct from the development of renal disease and retinopathy could be weakly founded. In Type II diabetes the degree of retinopathy might be seen later but it clearly correlates with that of glomerulopathy [78]. It is nevertheless still surprising and so far unexplained that some Type II patients have proteinuria, but not retinopathy, according to standard evaluation [78].
Another key issue is that more than one risk factor must be present for the development of apparent clinical disease. Thus isolated hyperglycaemia might not suffice to develop overt renal disease, whereas two co-existing risk factors namely, hyperglycaemia and high blood pressure, must be present as underscored in the UK prospective diabetes study [79, 80]. Conversely the development of microalbuminuria is usually accompanied by the development of increased blood pressure. Therefore, there should be recognition of both risk factors. In long-term studies, in diabetic patients without clinically meaningful microvascular lesions, blood pressure is lower than in the general population which again supports the prerequisite of at least two risk factors in the genesis of renal disease [81].

Interestingly, clinical management was hampered for many years by the studies of Siperstein and coworkers [82] suggesting that morphological lesions can be present at or before the clinical diagnosis of diabetes. This would lend some support to genetic factors being decisive for the development of microvascular disease. A tempting, but dangerous conclusion would then be that the development of microvascular lesions is not responsive to better metabolic control but related to genetic "destiny" rather than to treatment failure [83]. These concepts were incorrect, at least for the kidney, as substantiated by the studies by R. Østerby who showed that structural lesions develop after diabetes has been present for some years [42-48]. Muscle basement membrane might be less suited to measurement [49].

In his long-term follow-up studies Pirart showed that for microvascular lesions and neuropathy, gly- 
caemic control was important [84]. Several European intervention studies confirm the correlation between hyperglycaemia and the development of renal disease [85]. It was not, however, until the Diabetes Control and Complications Trial (DCCT) [41] was completed that this was widely accepted in the United States, an attitude which, in retrospect, could in many places have had a deleterious effect on clinical management before 1993. This could also apply to the management of Type II diabetic patients, in whom metabolic control quite often is not perfect, but this will possibly change after publication of the UK prospective diabetes study [79].

Studies on genetic predisposition should be considered in the context of several risk factors [15]. Thereby certain angiotensin-converting enzyme (ACE) genotypes have been shown to possibly affect progression [86], although data are diverse and might not relate to all Western populations $[87,88]$ as the effect can possibly only be seen in large meta-analyses [86]. In Type II diabetes there seems to be no such effect in Caucasians [86]. Familial predisposition to hypertension, also seen in affected patients, could still be important in a concordant, yet multifactorial, fashion $[89,90]$ and blood pressure can be treated once the patients become hypertensive. Recent work also suggests some racial and familial clustering of renal disease in black patients [91-92] but often such patient-material is small and familial clustering of environmental factors are just as likely [93].

\section{Birth weight, hypertension and microalbuminuria}

It has been suggested that low birth weight could be predictive of cardiovascular renal disease in diabetes and in the general population [94]. Small kidneys could relate to fewer glomeruli and an increase in the pressure gradient in existing tissue. This concept was not, however, supported by our studies on the relations between birth weight, renal and glomerular size [95, 96]. Also in population-based studies we failed to find any correlation between microalbuminuria or raised albumin secretion and birth weight. Nor was there any correlation between blood pressure and birth weight [25]. Therefore it seems inconceivable that pathologically low birth weight could be an important determinant of essential hypertension or associated renal disease, in particular, because hypertension is highly prevalent in the Western population and found in perhaps $15-20 \%$ of elderly people. Hypertension is more closely related to actual increased body mass index or abdominal adiposity. A relation between low birth weight and the development of diabetes and some element of cardiovascular disease might however exist, although it is not consistent, is possibly weak, and is not relevant in the management of patients [97, 98].

\section{Immune-based measurement of albumin in low concentrations}

Progress in medical research is often driven by new methodology and procedures, e.g. by more sensitive techniques. This was the case with the study of early development and early treatment of diabetes associated renal disease. The first study describing measurements of albumin in normal urine was quite elaborate requiring pre-concentration of urinary albumin [99]. This completely changed after the introduction of radioimmuno assays for albumin that often even required dilution of urine samples and led to the term microalbuminuria [100]. The introduction of such methods was important in the study of the early diabetes-associated renal impairment in cross-sectional and longitudinal studies. Radioimmuno assays were, however, still laborious and time-consuming for clinical use and therefore it was an important step forward when immuno-turbidimetry and other immune precipitation tests were developed; this allowed processing of multiple samples of urine at high speed for use in clinical practice [12]. It was a major step forward in the clinical management of patients with diabetes and also those with essential hypertension $[17,101]$.

Clinical management has benefited further from the introduction of effective and quick bedside and dipstick tests for measurement of albumin. The introduction of the Micral 1 and Micral 2 tests which are not quantitative was of major benefit $[102,103]$, with the Micral 2 test being very efficient and easy to use in the clinic [103].

In our clinical laboratory a very good quantitative correlation has been obtained through the measurement of the albumin:creatinine ratio by the DCA2000 apparatus compared with measurement by immuno-turbidimetry [104]. Thereby it is possible to rapidly measure not only $\mathrm{HBA}_{1 \mathrm{C}}$ but also albumin and creatinine [104], an ideal situation for small clinics where large-scale measurements of these compounds are not always necessary. We have thus experienced huge progress in our laboratory techniques from the initial extremely laborious methods in the early 1960 s [99] to the very quick and efficient bedside tests of the 1990s [104].

\section{Microalbuminuria in Type I diabetes}

Three independent groups have consistently shown that microalbuminuria predicts overt renal disease $[73,105,106]$. Consequently it is now wide-spread clinical practice to screen for microalbuminuria, especially as it has subsequently been shown that intervention is effective (as described later). Follow-up studies of initial cohorts have also shown that microalbuminuria is strongly predictive of mortality from 
cardiovascular disease $[107,108]$. In a recent study with shorter follow-ups, on a very large number of patients, the same phenomenon was observed [109]. In this study the observation of the deleterious effects of albuminuria was also, however, based on patients with clinical proteinuria, excluded in previous studies because of their well-known poor outcome. In patients with long-standing diabetes and late microalbuminuria it can be assumed microalbuminuria increases relatively slowly [110]. Therefore these patients perhaps have a somewhat different and more "benign" prognosis than "fast track" patients, diagnosed early on with microalbuminuria or proteinuria. Such interpretations could, however, still be problematic because we are not dealing with two distinct entities but rather have regarded microalbuminuria as a continuous variable.

\section{Microalbuminuria in Type II diabetes}

In a follow-up study first communicated in 1983 [111] it was shown that microalbuminuria in Type II diabetes is strongly predictive of an increased mortality risk [112]. This observation has since been confirmed in numerous studies [113]. Other factors could be associated with poor prognosis such as long-term hyperglycaemia and high blood pressure. Microalbuminuria seems though to be the strongest overall predictor of mortality as has also been found in non-diabetic population-based studies [8]. Interestingly, poor metabolic control has recently been shown to predict microalbuminuria [114, 115] and could also be a risk factor for its progression, whereas high blood pressure can be more important later on [114, 116-125]. Poor glycaemic control correlates with typical diabetic glomerular lesions [126]. More so-called "unspecific" lesions can also be observed but non-diabetic microalbuminuric controls are lacking, which is problematic. Indeed there might be some misclassification of patients in such studies because albuminuria usually decreases with antihypertensive treatment [126]. The "unspecific" lesions can also be considered as characteristic lesions in diabetic patients, again making exact classification problematic not necessarily in daily ordinary pathology practice but in scientific work which is to be tested by other investigators. Other studies have shown abnormalities in microalbuminuric Type II diabetic patients [127]. Among the many risk factors analysed [118-124] hyperglycaemia and hypertension seem to be of particular importance, as documented in initial studies on the relevance of higher albumin excretion rates in relation to other risk factors [8-10]. Thus again there is a requirement for two risks; hyperglycaemia and high blood pressure factors must combine to produce important clinical disease $[114,116]$. Since microalbuminuria in Type II diabetes is a better predictor of cardiovascular than of microvascular disease other macrovascular disease factors must be taken into consideration. These include hyperlipidaemia whose reduction plays an important part in secondary prevention of cardiovascular disease in Type II diabetes.

The natural history of microalbuminuria in Type II diabetes has been surveyed recently [116]. Short-term intervention treatments are not usually very effective $[119,125]$. Long-term glycaemic control as in the $\mathrm{Ku}-$ mamoto study [40] and the UK prospective diabetes study [128-131] have, however, proven rather efficient especially when combined with long-term antihypertensive treatment $[130,131]$. Detailed accounts of microalbuminuria in the UK study are still awaited.

\section{Difference between Type I and Type II diabetes}

More and more evidence suggests that the course of renal abnormalities is similar in Type I and Type II diabetes. Obviously, there are exceptions because patients with Type II diabetes tend to be elderly and obese. This means hypertension is seen much earlier in Type II diabetes with subsequent renal damage. Another important point is that Type II diabetes can remain undiagnosed for many years and therefore many patients will have renal and retinal as well as cardiovascular damage at the first clinical diagnosis [29]. Risk factors for the development of renal disease include poor metabolic control and high, or increasing, blood pressure for both types. With microalbuminuria again glycaemic control and high blood pressure are important risk factors that can be controlled. In overt renal disease, there is a clear-cut correlation between blood pressure and decline in glomular filtration rate. There is also a correlation in Type I diabetes between glycaemic control and a decline in GFR $[87,88]$ but this is less clear in Type II diabetes where there seems to be no correlation between rate of decline of GFR and $\mathrm{HbA}_{1 \mathrm{C}}$ [116].

Treatment modalities seem to be the same as confirmed by the UK prospective diabetes study [128-131]. An important point is that many patients with Type II diabetes have cardiovascular and cerebrovascular disease and might suffer premature mortality. Certainly, this can be modulated by early antihypertensive treatment as shown in several trials [132-138] (Table 8) and also by lipid lowering [139].

\section{Microalbuminuria in population-based studies}

Microalbumininuria is present in $5-10 \%$ of elderly populations $[20,28]$ and usually relates to hypertension but also to other risk markers of cardiovascular disease, such as abdominal obesity, hypertension and hyperuricaemia. The relation between microalbuminuria and early mortality in population-based stud- 
Table 8. Positive effect on cardiovascular end points in Type II diabetes by AHT

\begin{tabular}{ll}
\hline & FAVOURS: \\
\hline 1. SHEP [137] & Diuretics vs placebo \\
2. ABCD [135] & ACE-I vs CCB \\
3. Facet [132] & ACE-I vs CCB \\
4. HOT [134] & Strict control (CCB-based) \\
5. UKPDS [130] & Strict control (ACE-I + $\beta$-bl-based) \\
6. SYST-EUR [133] & CCB vs placebo \\
7. CAPPP [136] & ACE-I vs conventional \\
\hline
\end{tabular}

AHT, antihypertensive treatment; $\mathrm{CCB}$, calcium channel blockers; $\beta$-bl, beta-blockers

ies was first documented more than 10 years ago [20, 27]. Accordingly microalbuminuria should be included in epidemiological studies with a focus on cardiovascular and metabolic diseases. In essential hypertension, microalbuminuria is often diagnosed and predictive of cardiovascular and also of progressive renal disease [101]. This is relevant to "Syndrome $X$ " where similar observations were made decades ago by Kylin in 1923, Himsworth in the 1930 s, Vague in the $1940 \mathrm{~s}$, and Avogaro and Crepaldi in 1965 [140-144]. It is, however, still perhaps a too vaguely defined entity [145] which often most strongly relates to simple obesity. In contrast microalbuminuria is more related to high blood pressure and diabetes as shown in the Hoorn Study [30] and should not be included in the "syndrome".

\section{Provocation tests to detect early abnormalities in renal function}

It was shown several years ago by Karlefors [146] that exercise induces a clear-cut increase in blood pressure, in particular, in diabetic patients with renal complications and blood pressure values in the upper normal range. We used this concept to describe and detect nascent changes in renal function prior to microalbuminuria and in certain patients quite a pronounced increase in albuminuria occurred during exercise, especially in those with pre-existing microalbuminuria [147-150]. Increases in albuminuria are associated with raised blood pressure during exercise, an association that is quite strong. It is, however, not clear whether this test is predictive of advancing renal disease. Although the idea seems quite attractive, clear-cut, follow-up studies have not been conducted. Therefore, in the clinical situation multiple baseline measurements are preferred to precisely define the degree of early renal involvement. To this end we measure the albumin: creatinine ratio at each visit to the clinic [12]. It has also been proposed that tests that block tubular reabsorption, e.g. by lysine or other dibasic amino-acids be used but again these are too laborious for clinical use [151, 152] although, important physiological information on the nature of renal involvement in diabetes has thereby been obtained. By apparent complete blockade of tubular reabsorption, albumin excretion rises from 5 to approximately $300 \mu \mathrm{g} / \mathrm{min}$, thus providing an estimate of transglomerular passage of albumin $[57,151]$. In addition other provocation tests have been examined [153-157].

\section{4-h Ambulatory blood pressure measurements}

Ambulatory blood pressure measurements were first developed in the 1960s by Sokolow's [158] and Pickering's group [159] and in the $1980 \mathrm{~s}$ by Rubler in diabetic patients [160]. The technique used was initially quite difficult and demanding not only for the patient but also the physician. With the introduction of more user-friendly equipment, such as the SpaceLabs apparatus, it is now common clinical practice to take ambulatory blood pressure measurements in situations where there is uncertainty as to the precise level of blood pressure, both before and during treatment [161-174]. An important confounding issue to be avoided is the situation-induced "white-coat" hypertension which is just as common in diabetic as in non-diabetic patients $[175,176]$. This is also extremely important in clinical trials because fewer patients could be required to document treatment effects $[162,177]$. More sophisticated questions might be answered by ambulatory blood pressure measurements. These include: 1) the effect of smoking which seems to increase blood pressure in diabetic patients in contrast to the paradoxical reduction in ambulatory blood pressure in non-diabetic patients [178]; 2) the lower blood pressure in healthy women which is now well established but this conceivably protective biological feature is lost in diabetic patients [165]; 3) the significance of a lack of nocturnal blood pressure "dips" in diabetic patients about which there are still some doubts [175]. In people with normoalbuminuria we have not found any major differences between those with and without diabetes and the phenomenon of dipping has been quite variable and not applicable in clinical settings [175]. It has, however, been reported that Type I diabetic patients on intensive insulin therapy to some extent lack nocturnal dipping [179].

It is important to take ambulatory blood pressure when describing the antihypertensive effect of drugs, e.g. angiotensin-converting enzyme inhibitors [162, $175,178]$. Thus, it is sometimes not possible, with the use of clinically based blood pressure, to detect a reduction in blood pressure that can only be unveiled during ambulatory blood pressure recordings. If it were not for these it could be argued that the inhibitors are renoprotective, even without any detectable effect on blood pressure. Thus by taking the ambulatory blood pressure we observed some blood pressure reduction in such patients, even in trials with relatively few patients [177]. Again, this illustrates the danger 
of limiting the concept of renoprotection, by excluding the beneficial effect of blood pressure reduction. Multiple blood pressure measurements with the most exact procedures are therefore essential.

\section{Dextran clearance}

Dextran clearance was introduced to describe the glomerular permeability to a large range of molecular sizes [180] and the principle was then used in diabetic patients $[181,182]$. When we introduced this technique in our laboratory for diabetic patients $[2,72]$ we saw no change in dextran clearance in patients with either newly diagnosed diabetes or long-standing diabetes when correcting for prevailing glomular filtration rate [72], since these patients are often hyperfiltering. In patients with microalbuminuria, Deckert [183], in contrast to other studies [184, 185], also failed to find any changes. We were, however, able to see changes in patients with advanced clinical proteinuria but only by long-term collection of urine after dextran infusion and use of very high-molecular weight dextran [2]. Thus in patients with advanced proteinuria only small permeability defects could be described, which could be a paradox because these patients were clearly proteinuric or even nephrotic. Possibly the dextran molecule is not suitable for this purpose, perhaps because it uncoils during the glomerular filtration process and charged dextrans possibly aggregate suggesting a falsely low clearance. The introduction of Ficoll - a molecule with more fixed structure - could or could not provide new information on glomerular permeability to large molecules. Still, in the clinical situation, it is much easier and more practical to use endogenous plasma proteins as markers.

\section{Renal and other organ protection}

To define risk markers for progressive renal as well as cardiovascular disease is clearly of interest academically but not necessarily of clinical importance as intervention might not always be possible. Theoretically, intervention should certainly be possible considering the two major risk factors, high blood pressure and hyperglycaemia. Renal protection, defined as any measure to prevent progression of renal impairment, could therefore include control of blood pressure and hyperglycaemia, based on observational risk factor studies, as poor glycaemic control is a major risk factor for progression from normo- to microalbuminuria $[114,115,171]$. In patients with microalbuminuria, glycaemic intervention is not, however, always clinically feasible, although highly desirable $[15,186-188]$. The background could well be that patients with microalbuminuria previously have had poor metabolic control which could be inherently difficult to treat. In overt nephropathy, poor metabolic control is certainly associated with rapid progression $[15,87,88]$. Therefore during the entire course of renal involvement in diabetes good metabolic control is a main issue, likewise for the prevention of retinopathy, as well as, to some extent, cardiovascular disease, both in Type I and Type II diabetes. Table 7 describes the relation between intermediary end-points and the decline in glomular filtration rate. This is a dramatic development over the last 40 years as it has been argued that hypertension was "essential" to maintain sufficient organ perfusion and survival [35].

\section{Early anti-hypertension treatment to prevent progression in renal disease in microalbuminuric patients}

In this context it is important to consider blood pressure as a continuous variable [189]. It cannot be argued that there is a clearly defined level representing high blood pressure unless long-term studies are conducted to observe correlation between blood pressure and development of cardiovascular and renal lesions. This applies to both Type I and Type II diabetes and the general population. Certainly diabetic patients could be more susceptible to renal damage than non-diabetic people or patients with essential hypertension, as related to blood pressure [18, 147].

This was the basis for our early intervention study in which microalbuminuric Type I diabetic patients with so-called "normal" blood pressure were enrolled in a clinical trial with a self-controlled approach [189-191]. In this study it was documented that antihypertensive treatment with beta-blockers could lead to regression of microalbuminuria. Further studies along this line showed that antihypertensive combination treatment in such patients is associated with declining albuminuria and slow progression (no decline in GFR) in early diabetic renal disease [192-194]. At present most diabetic patients are on combination therapy.

The benefit of this new therapy was clearly confirmed using angiotensin-converting enzyme inhibitors in the treatment of patients with microalbuminuria [195]. Numerous studies [196-203] have confirmed the effect of these inhibitors in Type I diabetes leading to regression of microalbuminuria, as also documented in a recent meta-analysis [203]. Interestingly, this effect is also seen in very early renal involvement in diabetes, such as in patients with mild microalbuminuria [177] between 20 and $70 \mu \mathrm{g}$ per min. In this 2-year controlled clinical trial the progression expected was seen in the untreated control group with a mean increase rate between 15 and $20 \%$. With treatment using ACE-inhibition, there was a clear-cut reduction in albuminuria as seen in 
earlier studies in which the subjects had a higher degree of microalbuminuria. Therefore treatment could be effective quite early, just after the development of microalbuminuria as now advocated by recent guidelines [204]. In the study [177], the specific renal impact of ACE-inhibition was clearly documented. A fall in albuminuria correlated with a fall in filtration fraction. The long-term aim is, however, not regression of microalbuminuria per se, although this might be a reliable surrogate marker, but to prevent a decline in GFR. This requires long-term studies over 6-8 years. Indeed Mathiesen and co-workers [197] were able to show that the effect of ACE-inhibition is not always long lasting. Importantly, patients with clinical proteinuria had well-preserved GFR after a pause in treatment but only when ACE-inhibitors had been given over the previous 8 years. Without antihypertensive treatment, there was a clear-cut decline in GFR in those developing proteinuria. This is the first study to document a long-term preservation of GFR in Type I diabetes [197] as seen in Type II diabetes [200, 201].

\section{Renal protection in Type I diabetes with overt nephropathy}

There has been some discussion about the definition of renal protection in diabetes and in other renal diseases. In my view, a key point is that renal protection should mean GFR is better preserved by treatment, irrespective of its modality. It has been proposed that "renal protection" should be defined as a kind of treatment that preserves GFR, on top of the effect of blood pressure reduction. In my mind this definition is too narrow. Any kind of treatment that prevents a fall in GFR or reduces fall rates in GFR should be termed reno-protection. A broader and weaker definition would be "reduction in proteinuria" since this nevertheless is often associated with the prevention of decline in GFR [15].

Initially, we studied early renal involvement in diabetes describing the now well-known phenomenon of hyperfiltration $[1,72,205,206]$. Subsequently it was found pertinent to study the natural course of renal function changes in diabetic patients, especially in those with microalbuminuria and clinical proteinuria [207-210]. It became clear that a rise in blood pressure was associated with a fall per period of time in GFR in proteinuric patients and therefore anti-hypertensive trials were initiated with a self-controlled design. This was essential to gain optimal sensitivity due to the limited number of patients available [211].

It soon became clear that antihypertensive treatment with beta-blockers and diuretics and sometimes vaso dilatators was quite effective in preserving GFR [211-214] and in improving renal prognosis [215, 216]. These seem to be the first studies to document

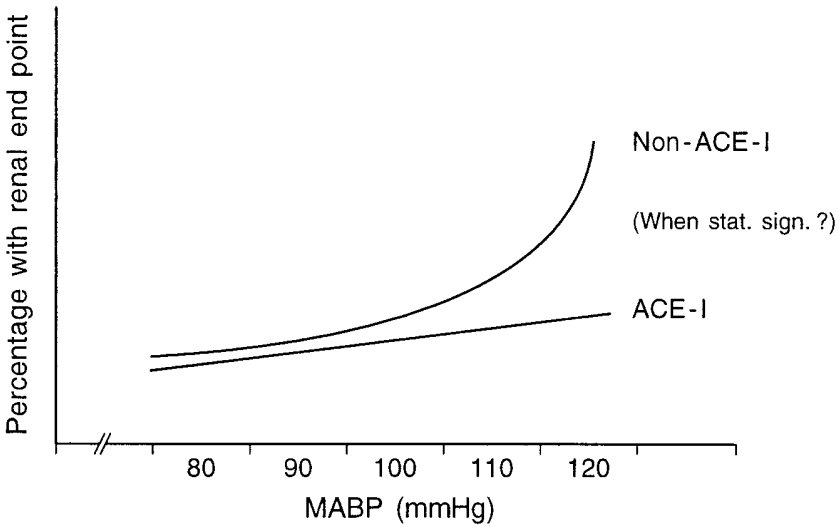

Fig. 2. Nephropathy in Type I diabetes. The concept of renal protection in relation to blood pressure according to E. Lewis [218]. $\mathrm{MABP}=$ mean arterial blood pressure. At which level is blood pressure differing significantly?

reno-protection (using the above definition) by antihypertensive treatment in diabetes specifically and in renal disease in general. Later studies were conducted in other centres, in particular in Sweden [217] in patients with overt diabetic renal disease. All results suggested that the fall rate in GFR could be reduced by about 50 per cent from $10 \mathrm{ml} \cdot \mathrm{min}^{-1} \cdot$ year $^{-1}$ to $5 \mathrm{ml} \cdot \mathrm{min}^{-1} \cdot$ year ${ }^{-1}$ or even more by more effective antihypertensive treatment $[15,214]$. To some extent, this effect seems to be independent of the type of antihypertensive treatment and depends rather more on blood pressure reduction per se although there could be some disagreement [15]. The largest study so far conducted in overt renal disease in patients with Type I diabetes was the Collaborative Study in the United States [218]. Again this showed antihypertensive treatment to be effective in Type I diabetes. The study compared the use of ACE-inhibitors with other agents to control blood pressure. With a lower and more satisfactory degree of blood pressure attained during treatment, the effect with ACE-inhibitors and other agents was the same (Lewis, personal communication) as illustrated in Figure 2. In contrast with higher blood pressure the ACE-inhibitors seemed to be more efficient, although a strict cut-off has never been defined [219]. In other studies it was found that the blood pressure level was important for the determination of the rate of decline in GFR and also some effect was observed by $\mathrm{HbA}_{1 \mathrm{C}}$ as seen in other studies [15]. In Weidmann et al.'s meta-analysis [220] on proteinuria as a surrogate marker the effect of ACE-inhibition became progressively less as lowering of blood pressure was more intense [219]. In non-diabetic renal disease ACE-inhibition is also an important treatment strategy [221].

In my mind, it is not productive to exclude, by definition, antihypertensive treatment as a reno-protective measure. I would prefer that all measures which protect against a decline in GFR be included in the 


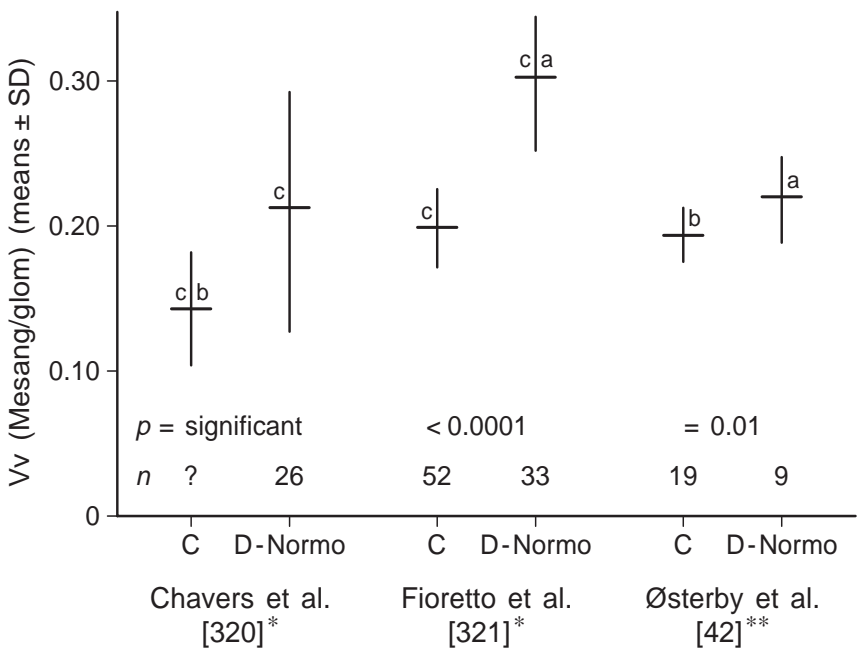

Fig.3. Type I diabetic patients with normoalbuminuria (D) and non-diabetic renal donors (C). Data from Minneapolis and from Aarhus. a b, of note the large differences between Aarhus and Minneapolis. c Surprisingly big differences between two sets of data from Minneapolis. *Request for pancreas transplant (why?). **Protocol biopsies

definition both in diabetes and in other renal diseases. It is clear that antihypertensive treatment is important, however, in most renal diseases as suggested by our long-term studies in 1982 [211], subsequently confirmed [219], also for cardiovascular disease [130,131].

\section{Glycaemic control and glycaemic measures}

It would seem plausible that diabetic lesions in the kidney and in the eyes, specific for diabetes, are caused by the diabetic state, especially hyperglycaemia. For many years, there was doubt however about this association, mainly because of difficulties in documenting long-term glycaemic control. The large-scale observational study conducted by Pirart and co-workers, however, showed a clear correlation between glycaemic control and the development of microvascular and neurological complications [84]. Intervention studies conducted in Scandinavia and elsewhere supported these observations [15] which were later confirmed by the DCCT as to the development of microvascular and possibly also macrovascular lesions. This formed the basis of the concept of glucotoxicity [41]. Nyberg et al. were the first to observe fairly stable GFR in patients with well-controlled metabolism [222] which was later confirmed [87, 88]. They showed that the decline in the rate of GFR correlated with $\mathrm{HbA}_{1 \mathrm{C}}$ and strong evidence for an earlier effect was obtained in the DCCT [41]. Thereafter, optimal glycaemic control became the elusive golden standard for care in Type I diabetes. Most experts would very much support this view, also for Type II diabetes, when intervention studies related to microvascular disease are positive [40] and there is also a clear correlation between glycaemic control and the development of complications in observational studies [186].

Over the past 25 years, we have observed a radical change in the management of patients, driven by new methods, such as home monitoring of blood glucose, insulin pumps, insulin pens, along with better monitoring of glycaemia, as well as better documentation of complications as measured by retinal photographs and microalbuminuria. Although insulin pumps were introduced around 1980 [223] and stimulated our hope for a practical way to achieve near-normoglycaemia [224-232], for many reasons they are used nowadays by fewer and fewer patients.

Pancreas transplantation, as a more radical approach towards euglycaemia, was proposed even earlier and was also thought to have great promise [233-235]. The idea and its considerable impracticality has been evaluated recently [236]. A new longterm study [237] suggested that the glomerular lesions in diabetic nephropathy could heal not after 5 but after 10 years of normoglycaemia effected by isolated pancreas transplantation. It should be noted that three of the eight patients in fact initially had normoalbuminuria, which in our experience (by strong contrast to the Minneapolis group) is associated with very limited lesions [47] (Fig. 3) and by definition such patients do not have nephropathy $[14,15]$. Four patients had microalbuminuria and only one proteinuria, that is only one with overt nephropathy. Only open, nonsclerosed glomeruli were evaluated and no information on change in number of occluded glomeruli is available. Also analysis of interstitial expansion or vascular lesions would have been important considering necessary long-term treatment with Cyclosporin A. Biopsies were not taken from two patients at the follow-up because they had developed end-stage renal disease, so they were hardly normal again from any point of view. The follow-up rate of the very initial total cohort (at year zero) is not recorded. A fall in GFR (from 108 to $74 \mathrm{ml} / \mathrm{min}$ ) was noted in patients that were followed for 10 years, hardly a sign of regression. It would be important to see this study confirmed but for practical reasons this is not to be expected. The study could have problematic implications if it were to create overoptimistic views on the usefulness of pancreas transplantations. Also it is noteworthy that pancreas transplantation does not always lead to a complete return to normal metabolism [238].

\section{Angiotensin-converting enzyme-inhibitors}

Angiotensin-converting enzyme-inhibitors are antihypertensive agents which in several experimental studies [239], and also in human studies in diabetes [195], had a specific effect on renal function reducing 
trans-glomerular pressure. Thereby, a reduction in albuminuria has been shown by ACE-inhibitors; likewise, the rate of decline of GFR and even its arrest was seen in patients with microalbuminuria [197]. Therefore, the use of ACE-inhibitors has become a standard initial choice in early and late antihypertensive treatment of diabetic patients, but quite often combination therapy is required, also in clinical trials [196]. It is still debatable whether, with exactly the same effects on blood pressure, differences still remain between ACE-inhibitors and other anti-hypertensive agents though this argument has been resolved for beta-blockers, which exert the same beneficial action as ACE-inhibitors in Type II diabetes [131]. Nevertheless the debate seems to have been largely academic as usually ACE-inhibitors are quite efficient and only have a few side effects (no impact on glycaemia), at least early in the course of renal involvement in diabetes. In any case, the introduction of ACE-inhibitors has been a major step forward in diabetes care. We are still working on a new development combining ACE-inhibitors with diuretics and cardio-selective beta-blockers as a potentially even more efficient treatment [194]. Years ago, it was suggested that antihypertensive treatment could impair renal circulation and thus be deleterious [35]. The small reduction in GFR along with reduced proteinuria is likely to be indicative of a beneficial effect [15]. Based on many studies, we now know that low blood pressure obtained by treatment or spontaneously is protective against the development of more advanced glomerulopathy and decline in GFR [219]. Renal vascular stenosis in diabetic patients very rarely imposes clinical problems [130, 131] and needs usually not to be screened for before treatment [240].

\section{The concept of antihypertensive combination therapy in diabetes}

Quite often in clinical practice antihypertensive combination therapy has to be used. This is not surprising considering the complex nature of high blood pressure in diabetes. With particular regard to renal involvement it could be advantageous to use ACE-inhibitors because of their effect on glomerular pressure $[36,239,241]$. Indeed, there could also be an additional effect on growth factors and cytokines by ACE-inhibition. Nevertheless, early on there could also be general hyperfusion related partly to cardiac involvement [242] that could be reduced by the use of beta-blockers. This concept of general vascular hyperfusion in the genesis of vascular complications was proposed by Parving et al. [243]. In many Type I and Type II diabetic patients there are signs of sodium retention and therefore diuretic treatment could be beneficial.
Following these lines we have used a combination of beta-blockers and ACE-inhibitors [192, 193, 194] with diuretics as a basis therapy. This kind of treatment was effective in reducing albuminuria and persistent studies have shown long-term preservation of GFR in patients with early renal disease [194]. Therefore, this concept of treatment could prove important, also in the early management with only limited blood pressure increase. Very few side-effects are seen with early combination therapy where moderate doses can be used. This concept could well prove profoundly renoprotective in long-term studies.

\section{Renal involvement and treatment in patients with Type II diabetes and proteinuria}

Patients in this category have a poor prognosis with a rapid decline in GFR, correlated with blood pressure, but not $\mathrm{HbA}_{1 \mathrm{C}}[15,244]$. The prognosis is also poor because many patients develop cardiovascular disease which is the most common reason for the observed considerable increase in mortality. Therefore, it is important to conduct new trials in this area, indeed two major trials are in progress using treatment with an angiotensin-converting receptor blockade compared with standard treatment. In one study, treatment with calcium channel blockers is used in one arm. Some controversy has arisen recently regarding calcium channel blockers in diabetes [245, 246]. The results of large new trials are eagerly awaited, in the hope it will be possible to improve the care of these patients. In my mind, however, it is clear that early treatment, including screening of patients with microalbuminuria and well-preserved GFR would still be essential along with early antihypertensive treatment in general and better glycaemic control.

So far treatment with the receptor blocker Losartan has been effective in normoalbuminuric and microalbuminuric essential hypertensive patients [247]. In normoalbuminuric Type I diabetes, Losartan not only reduces blood pressure (in normotensive patients) but also hyperfiltration and insulin resistance and this is of potential benefit in Type II diabetes [248]. The clinical relevance remains though to be established.

\section{The natural history of diabetic renal disease, a sound concept?}

The term "the natural history of diabetic renal disease" has been widely used [249] but possibly it is no longer appropriate simply because we have and use many measures to change the course of renal disease in diabetic patients. The natural history can be a term used to describe the normal course in diabetic 
patients in purely observational studies. It is however now clear that the course of renal disease strongly relates to glycaemic control and with $\mathrm{HbA}_{1 \mathrm{C}}$ lower than $7.5 \%$ microalbuminuria might not develop at all. Also when microalbuminuria is present there could be an effect of improved glycaemic control although this is difficult since control is often hard to achieve in these patients [188]. In overt renal disease several observational studies in Type I diabetes have shown that the rate of decline in renal function is correlated with $\mathrm{HbA}_{1 \mathrm{C}}$ which excludes the term "natural history" and obviously only applies to untreated patients. In the case of normal blood pressure the rate of decline in GFR is actually low and long-term studies have shown that survivors with diabetes of more than 40 years duration quite frequently have lower than normal blood pressure [81].

\section{Cardiovascular and cerebrovascular along with renal end-points}

Cardio and also cerebrovascular diseases are major causes of death in both Type I and Type II diabetes, especially when the kidney is affected. Although the concept of controlled clinical or therapeutic trial has evolved over the past 50 years [250-251], only a few large trials have been conducted in diabetes, the first being the UGDP (University Group Diabetes Program) [252] which is now, after the UKPDS [128-129], mainly of historical interest. No real large-scale controlled trials were done when introducing sulphonylureas [253], biguanides or insulin but this has changed now [128-129]. There has therefore been an increasing interest in cerebrovascular and cardiovascular end-points, especially in Type II diabetes with respect to effective modulation, mainly with antihypertensive treatment strategies, which show a beneficial effect (Table 8). Most studies use ACE-inhibitors but it is noteworthy that any reduction in blood pressure seems to be important. Certain trials show ACE-inhibitors to be superior to calciumblockers and also conventional treatment [132, 135, 136]. Importantly, the UK prospective diabetes study showed a similar outcome using ACE-inhibitors and beta-blockers [128, 129]. Fewer side effects occurred with the use of ACE-inhibitors. This study also clearly showed that careful blood pressure monitoring and effective treatment reduce very considerably cardio and microvascular end-points (around $30 \%$ ). Therefore, antihypertensive treatment should be given great priority in the management of patients with Type II diabetes. The UK prospective diabetes study showed some effect of optimal glycaemic control but due to the nature of the trial this was not so evident. Combined euglycaemia $\left(\mathrm{HbA}_{1 \mathrm{C}} \approx 6-7 \%\right)$ and normotension is, however, highly protective when blood pressure is around $130 / 80[79,80]$.

\section{Meta-analysis in diabetes}

The meta-analysis approach was originally worked out in the physical and mathematical sciences [250, 251] but was soon used in medical studies to combine, for instance, data from trials and from observational cohorts, e.g. on the correlation between hard endpoints such as mortality compared with risk factors such as blood pressure. Indeed studies with observations in many subjects have documented a clear linear correlation between hard end-points and blood pressure down to normal values.

Parving et al. did a meta-analysis of many small trials in the evaluation of progression of renal disease in Type I diabetic patients treated with ACE-inhibitors and non-ACE-inhibitors and found very similar progression rates during treatment [15, 214]. The analysis was before the Ed Lewis Study [218]. Most trials with microalbuminuric patients in Type I diabetes are of limited size and therefore it would be valuable to do meta-analysis also on such patients as done by Chaturvedi along with our group and others [203]. The beneficial effects on regression of microalbuminuria were better documented in this meta-analysis than in individual studies of homogeneous Type I diabetic patients.

It is important to consider homogeneity before preceding with any meta-analysis otherwise the situation can be problematic such as in the metformin arm of the UK prospective diabetes study [129] in which a beneficial effect was found in newly diagnosed obese people with diabetes. Later on in other patients with longer standing diabetes, poor glycaemic control and probably more advanced vascular damage, the beneficial effect of combination therapy (metformin plus sulphonylurea) was lost and an adverse effect was even noted. From a clinical point of view these two patient groups are different and in my view it is not relevant and even incorrect to make a meta-analysis in such a situation. There are, however, people who support the Petonian approach and believe that meta-analysis can be important even with non-homogeneity [254]. This has been questioned suggesting that meta-analysis does not always give the correct answer, especially if the question is not correctly formulated and patient material not homogeneous [255-261].

\section{Guidelines with origin in pathophysiological and clinical trials}

The World Health Organisation - International Society of Hypertension (WHO-ISH) Liaison Committee on hypertension was established in the mid-1970s and has subsequently produced several guidelines, the first in 1975 [262]. New guidelines have recently appeared [263] also related to hypertension in diabetes. 
Table 9. Suggested target blood pressures during antihypertensive treatment. Systolic and diastolic should both be attained e.g. $<140 / 85 \mathrm{mmHg}$ means less than 140 systolic and less than 85 diastolic

\begin{tabular}{llllll}
\hline & \multicolumn{2}{l}{ Clinic BP } & & \multicolumn{2}{l}{ ABPM or home BP } \\
\cline { 2 - 3 } \cline { 5 - 6 } & No diabetes & Diabetes & & No diabetes & Diabetes \\
\hline Titrate to DBP: & $\leq 85$ & $\leq 80$ & $\leq 80$ & $\leq 75$ \\
Optimal BP: & $<140 / 85$ & $<130 / 80$ & & $<130 / 80$ & $<125 / 75$ \\
Suboptimal BP: & $\geq 150 / 90$ & $\geq 140 / 85$ & & $\geq 140 / 85$ & $\geq 130 / 80$ \\
\hline
\end{tabular}

${ }^{a}$ In those with high cardiovascular risk and initial blood pressure 140-159/90-99 $\mathrm{mmHg}$ there could be a case for adopting the targets for diabetic patients (British Hypertension Society 1999).

ABPM, ambulatory blood pressure monitoring

Several of these new guidelines have a similar approach [264-269]. There is a clear emphasis on early and effective antihypertensive treatment in patients with diabetes suggesting a lower threshold for the start of the treatment and also a lower blood pressure goal during treatment. Angiotensin-converting enzyme-inhibitors are often preferred as initial agents but combination therapy is often warranted. In view of the recent observation that different types of drugs (ACE-I, beta-blockers, calcium channel blockers and diuretics) reduce cardiovascular risk in Type II diabetes there are different treatment options. In diabetic renal disease ACE-I is however preferred. We should aim to achieve a blood pressure around 135/ $85 \mathrm{mmHg}$ during treatment (Table 9).

The British Hypertension Society proposes [266]: (1) "The threshold for antihypertensive treatment in Type I diabetes is $\geq 140 / 90 \mathrm{mmHg}$. The target blood pressure is $<130 / 80 \mathrm{mmHg}$, or lower $(<125 /$ $75 \mathrm{mmHg}$ ) when there is proteinuria $\geq 1 \mathrm{~g} / 24$ hours" and (2) "trials support treatment of all patients with Type II diabetes and blood pressure $\geq 140 / 90 \mathrm{mmHg}$, aiming for a target blood pressure $<130 / 80 \mathrm{mmHg}$. Blood pressures $\geq 140 / 80 \mathrm{mmHg}$ on treatment should be considered sub-optimal" and (3) "Thus there is evidence from outcome trials in hypertensive patients with diabetes for the efficacy and safety of ACE-inhibitors, betablockers, dihydropyridines, and low-dose thiazides. The choice among these drug classes should be made using the criteria set out earlier for non-diabetic patients. Blood pressure control will usually require more than one antihypertensive drug, and about $30 \%$ of hypertensive patients with diabetes need three or more agents in combination" [266]. A similar approach is seen in Table 9.

The problem is that it can be difficult to achieve such blood pressure in patients with proteinuria and overt renal disease and also in others with cardiovascular problems. Therefore, it is strongly advocated that treatment is started early, e.g. with development of microalbuminuria, even in patients with normal blood pressure. It has also been proposed that treat- ment should be started even before microalbuminuria [210]. Since complications are so closely associated with blood pressure increase (also in the normal range) this could easily be recommended in future guidelines as we now have effective treatment with limited side effects.

\section{Concluding remarks}

This review describes observations in a number of areas related to diabetic renal disease and related topics. Over the past 30 years there has been a great change in the management of the patients with longterm diabetes as described by Lundbæk [270], based on the results of physiological and patho-physiological studies followed by clinical trials which have been quickly implemented into clinical practice and incorporated in revised guidelines. Not all ideas have proved successful although they might have provided important insight into the nature of the disease. Some erroneous concepts have, however, led to setbacks slowing down the introduction of effective treatment in patients. These include a few very preliminary studies which suggested complications are predominantly genetically determined and therefore not readily modifiable. Considering complications to be generated primarily by a combination of glycaemic and haemodynamic factors (especially high blood pressure) - only partially genetically determined makes the treatment option much more attractive to the clinician [271,272].

The role of low protein diet is not discussed but the potential nephrotoxic effect of dietary proteins was originally explored by Anitschkow and co-workers in St. Petersburg in 1913 [273]. This gave rise subsequently to the cholesterol research since he fed rabbits so they were not only exposed to a high protein but also a high fat diet. The protein contents of the diabetic diet is still discussed [53, 274] but the cholesterol issue in diabetes, later appeared to be even more important [59].

Acknowledgements. This review is dedicated to laboratory assistant Merete Møller, who over the years helped me and my co-workers to conduct the studies described herein. I am most grateful to A. Honoré for secretarial work and to A. Andersen for reference management.

\section{References}

1. Mogensen CE (1989) Hyperfiltration, hypertension, and diabetic nephropathy in IDDM patients. Based on the Golgi Lecture 1988, EASD meeting, Paris. Diabetes Nutrition \& Metabolism 2: 227-244

2. Mogensen CE, Christensen CK, Vittinghus E (1983) The stages in diabetic renal disease. With emphasis on the stage of incipient diabetic nephropathy. Diabetes 32: 64-78 
3. Mogensen CE, Chachati A, Christensen CK et al. (1985-6) Microalbuminuria: an early marker of renal involvement in diabetes. Uremia Investigation 9: 85-95

4. Mogensen CE (1987) Microalbuminuria as a predictor of clinical diabetic nephropathy. Kidney Int 31: 673-689

5. Mogensen CE (1990) Prediction of Clinical Diabetic Nephropathy in IDDM patients. Alternatives to microalbuminuria? Diabetes 37: 761-767

6. Mogensen CE, Marshall SM (1990) Early diagnosis of diabetic nephropathy. Twelve assertions on microalbuminuria and early nephropathy. In: Andreucci et al. (eds) International Yearbook of nephrology. Kluwer Academic Publ., Boston, Dordrecht, London pp 123-146

7. Mogensen CE, Hansen KW, Klebe J et al. (1991) Microalbuminuria: Studies in diabetes, essential hypertension, and renal diseases as compared with the background population. In: Grünfeld JP (ed) Advances in Nephrology, vol. 20. Mosby Year Book, Chicago, Illinois, pp 191-228

8. Mogensen CE, Hansen KW, Østerby R, Damsgaard EM (1992) Blood pressure elevation versus abnormal albuminuria in the genesis and prediction of renal disease in diabetes. Diabetes Care 15: 1192-1204

9. Mogensen CE, Damsgaard EM, Frøland A (1992) GFRloss and cardiovascular damage in diabetes: A key role for abnormal albuminuria. Acta Diabetol 29: 201-213

10. Mogensen CE, Damsgaard EM, Frøland A, Nielsen S, de Fine Olivarius N, Schmitz A (1992) Microalbuminuria in non-insulin-dependent diabetes. Clin Nephrol [Suppl 1]38:S28-S39

11. Mogensen CE, Christensen CK, Christensen PD (1993) The abnormal albuminuria syndrome in diabetes. Microalbuminuria: Key to the complications. In: Belfiore F, Bergman RN, Molinatti GM (eds) Current Topics in Diabetes Research. Front Diabetes. Karger, Basel, pp 86-121

12. Mogensen CE, Poulsen PL, Heinsvig EM (1993) Abnormal albuminuria in the monitoring of early renal changes in diabetes. In: Mogensen CE, Standl E (eds) Concepts for the Ideal Diabetes Clinic. Diabetes Forum Series, Volume IV. Walter de Gruyter, Berlin, New York, pp 289-313

13. Mogensen CE (1999) Diabetic nephopathy: Natural history and management. In: Ei Nahas (ed) Mechanisms and clinical management of progressive renal failure. Oxford University Press, Oxford, in press

14. Mogensen CE (1998) Definition of diabetic renal disease in insulin-dependent diabetes mellitus based on renal function tests. In: Mogensen CE (ed) The Kidney and hypertension in diabetes mellitus, 4th ed., Kluwer Academic Publ, Boston, Dordrecht, London, pp 17-30

15. Parving H-H (1998) Renoprotection in diabetes: genetic and non-genetic risk factors and treatment. Diabetologia 41: 745-759

16. Parving H-H, Jensen HÆ, Mogensen CE, Evrin PE (1974) Increased urinary albumin excretion rate in benign essential hypertension. Lancet I: $1190-1192$

17. Bianchi S, Bigazzi R, Campese VM (1998) Microalbuminuria in patient with essential hypertension. Cardiovascular and renal implications. In: Mogensen CE (ed) The Kidney and hypertension in diabetes mellitus, 4th ed., Kluwer Academic Publ, Boston, Dordrecht, London, pp 569-584

18. Christensen CK, Krussel LR, Mogensen CE (1987) Increased blood pressure in diabetes: Essential hypertension or diabetic nephropathy? Scand J Clin Lab Invest 47: 363-370

19. Pedersen EB, Mogensen CE (1976) Effect of antihypertensive treatment on urinary albumin excretion, glomerular filtration rate and renal plasma flow in patients with essential hypertension. Scand J Clin Lab Invest 36: 231-237
20. Damsgaard EM, Mogensen CE (1986) Microalbuminuria in elderly hyperglycaemic patients and controls. Diabetic Medicine 3: 430-435

21. Damsgaard EM, Frøland A, Mogensen CE (1988) Albumin excretion above $15 \mu \mathrm{g} / \mathrm{min}$ is a strong predictor of death in elderly diabetics and non-diabetics. Diabetes Res Clin Pract 5 [Suppl 1]:S9 (Abstract)

22. Damsgaard EM, Frøland A, Jørgensen OD, Mogensen CE (1993) Prognostic value of urinary albumin excretion rate and other risk factors in elderly diabetic patients and nondiabetic control subjects surviving the first 5 years after assessment. Diabetologia 36: 1030-1036

23. Damsgaard EM, Frøland A, Jørgensen OD, Mogensen CE (1990) Microalbuminuria as predictor of increased mortality in elderly people. BMJ 300: 297-300

24. Vestbo E, Damsgaard EG, Mogensen CE (1997) The relationship between microalbuminuria in first generation diabetic and non-diabetic subjects and microalbuminuria and hypertension in the second generation (a population based study). Nephrol Dial Transplant 12 [Suppl 2]: 32-36

25. Vestbo E, Damsgaard EM, Frøland A, Mogensen CE (1996) Birth weight and cardiovascular risk factors in an epidemiological study. Diabetologia 39: 1598-1602

26. Vestbo E, Damsgaard EM, Frøland A, Mogensen CE (1995) Urinary albumin excretion in a population based cohort. Diabet Med 12: 488-493

27. Yudkin JS, Forrest RD, Jackson CA (1988) Microalbumuminuria as predictor of vascular disease in non-diabetic subjects. Lancet ii:530-533

28. Feldt-Rasmussen B, Jensen JS, Borch-Johnsen K (1998) Value of screening for microalbuminuria in people with diabetes as well as in the general population. In: Mogensen CE (ed) The kidney and hypertension in diabetes mellitus, 4th ed., Kluwer Academic Publ, Boston, Dordrecht, London, pp 151-162

29. Olivarius de FN, Andreasen AH, Keiding N, Mogensen CE (1993) Epidemiology of renal involvement in newly-diagnosed middle-aged and elderly diabetic patients. Cross-sectional data from the population-based study "Diabetes care in General Practice", Denmark. Diabetologia 36: 1007-1016

30. Jager A, Kostense PJ, Nijpels G, Heine RJ, Bouter LM, Stehouwer CDA (1998) Microalbuminria is strongly associated with NIDDM and hypertension but not with the insulin resistance syndrome: the Hoorn Study. Diabetologia 41: 694-700

31. Mogensen CE, Klebe JG (1998) Microalbuminuria and diabetic pregnancy. In: Mogensen CE (ed) The kidney and hypertension in diabetes mellitus, 4th edn., Kluwer Academic Publ., Boston, Dordrecht, London, pp 455-462

32. Ferrannini E (1993) The metabolic syndrome. In: Morgensen CE (ed) Target organ damage in the mature hypertensive. Science Press, London, pp 2.31-2.49

33. Mogensen CE, Hansen KW, Mau Pedersen M, Christensen CK (1991) Renal factors influencing blood pressure threshold and choice of treatment for hypertension in IDDM. Diabetes Care 14: 13-26

34. Mogensen CE, Mau Pedersen M, Hansen KW, Christensen CK (1992) Micro-albuminuria and the organ-damage concept in antihypertensive therapy for patients with insulindependent diabetes mellitus. Journal of Hypertension 10:S43-S51

35. Mogensen CE (1995) Diabetic Renal Disease: The Quest for Normotension - and Beyond. Diabetic Medicine 12: 756-769

36. Mogensen CE (1995) Management of the diabetic patient with elevated blood pressure or renal disease. Early screening and treatment programs. In: Laragh $\mathrm{JH}$, Brenner BM 
(eds) Albuminuria and Blood Pressure. Hypertension: Pathophysiology, Diagnosis, and management. 2nd ed., Raven Press Ltd. N. Y., pp 2335-2365

37. Mogensen CE (1990) Prevention and treatment of renal disease in insulin-dependent diabetes mellitus. Semin Nephrol 10: 260-273

38. Mogensen CE (1994) Renoprotective role of ACE inhibitors in diabetic nephropathy. Brit Heart J 72 (1):38-45

39. Mogensen CE (1994) Systemic blood pressure and glomerular leakage with particular reference to diabetes and hypertension. J Intern Med 235: 297-316

40. Ohkubo Y, Kishikawa H, Araki E et al. (1995) Intensive insulin therapy prevents the progression of diabetic microvascular complications in Japanese patients with non-insulin-dependent diabetes mellitus: a randomized prospective 6-year study. Diabetes Research Clinical Practice 28: 103-117

41. The Diabetes Control and Complications Trial Research Group (1993) The effect of intensive treatment of diabetes on the development and progression of long-term complications in insulin-dependent diabetes mellitus. New England Journal of Medicine 329: 977-986

42. Østerby R, Hansen R (1965) A quantitative estimate of the peripheral glomerular basement membrane in recent juvenile diabetes. Diabetologia 1: 97-100

43. Østerby R (1971) Course of Diabetic Glomerulopathy. Acta Diabet Latina 8 (1):179-191

44. Østerby R (1972) Morphometric studies of the peripheral glomerular basement membrane in early juvenile diabetes. I. Development of initial basement membrane thickening. Diabetologia 8: 84-92

45. Berg UB, Torbjörnsdotter TB, Jarenko G, Thalme B (1998) Kidney morphological changes in relation to long-term renal function and metabolic control in adolescents with IDDM. Diabetologia 41: 1047-1056

46. Østerby R (1990) Basement membrane morphology in diabetes mellitus. In: Ellenberg \& Rifkin's Diabetes Mellitus, theory and practice, 4th ed., Elsevier, N.Y., Amsterdam, London, pp 220-233

47. Østerby R (1996) Lessons from kidney biopsies. Diabetes Metabol Rev 12: 151-174

48. Bangsted HJ, Østerby R, Dahl-Jørgensen K, Berg KJ, Hartmann A, Hanssen KF (1994) Improvement of blood glucose control retards the progression of morphological changes in early diabetic nephropathy. Diabetologia 37: 483-490

49. Williamson JR, Vogler NJ, Kilo C (1971) Structural abnormalities in muscle capillary basement membrane in diabetes mellitus. Acta Diabet Latina 8 [Suppl 1]:117-134

50. Mau Pedersen M, Christensen SE, Christiansen JS, Pedersen EB, Mogensen CE, Ørskov H (1990) Acute effects of the somatostatin analogue on kidney function in Type 1 diabetic patients. Diabetic Med 7: 304-309

51. Mau Pedersen M, Christiansen JS, Mogensen CE (1991) Reduction of glomerular hyperfiltration in normoalbuminuric IDDM patients by 6 months of aldose reductase inhibition. Diabetes 40: 527-531

52. Mau Pedersen M, Mogensen CE, Christiansen JS (1995) Reduction of glomerular hyperfunction during short-term aldose reductase inhibition in normoalbuminuric, insulindependent diabetic patients. Endocrinology and Metabolism 2: 55-56

53. Mau Pedersen M, Mogensen CE, Schønau Jørgensen F, Møller B, Lykke G, Pedersen O (1989) Renal effects of limitation of high dietary protein in normoalbuminuric insulindependent diabetic patients. Kidney Int 36 [Suppl 27]:S115-S121

54. Mau Pedersen M, WintherE, Mogensen CE(1990) Reducing protein in the diabetic diet. Diabetes Metab 16:454-459
55. Mogensen CE (1986) Early glomerular hyperfiltration in insulin-dependent diabetics and late nephropathy. Scand J Clin Lab Invest 46: 201-206

56. Mogensen CE (1994) Glomerular hyperfiltration in human diabetes. Diabetes Care 17: 770-775

57. Mogensen CE, Sølling K, Vittinghus E (1981) Studies on mechanisms of proteinuria using aminoacid-induced inhibition of tubular reabsorption in normal and diabetic man. Contr Nephrol 26: 50-65

58. Mogensen CE, Christensen CK, Christensen NJ, Gundersen HJG, Jacobsen FK, Pedersen EB, Vittinghus E (1981) Renal protein handling in normal, hypertensive and diabetic man. Contr Nephrol 24: 139-152

59. Turner RC, Millns H et al. for the United Kingdom Prospective Diabetes Study Group (1998) Risk factors for coronary artery disease in non-insulin dependent diabetes mellitus: United Kingdom prospective diabetes study (UKPDS: 23). British Medical Journal 316: 823-828

60. Mogensen CE, Vigstrup J, Ehlers N (1985) Microalbuminuria predicts proliferative diabetic retinopathy. Lancet II:1512-1513

61. Gilbert RE, Tsalamandris C, Allen TJ, Colville D, Jerums G (1998) Early nephropathy predicts vision-threatening retinal disease in patients with type 1 diabetes mellitus. Journal of the American Society of Nephrology 9: 85-89

62. Bernard C (1849) Compte Rendu de la Société du Biologie. Paris. Vol. 1: 80-81

63. Deckert D (1998) Historical aspects of diabetes and diabetic renal disease. In: Mogensen CE (ed) The Kidney and hypertension in diabetes mellitus. 4th ed., Kluwer Academic Publ., Boston, Dordrecht, London pp 1-6

64. Rayer P (1839) Traité des maladies des Reins et des altérations de la sécrétion urinaire, etudiées en elles-mémes et dans leurs rapports avec les maladies des uretéres, de la vessie, de la prostate, de l'urèthre, etc. Libraire de l'Académie Royale de médicine, Paris

65. Rayer P (1841) Traité des maladies des Reins et des altérations de la sécrétion urinaire, etudiées en elles-mémes et dans leurs rapports avec les maladies des uretéres, de la vessie, de la prostate, de l'urèthre, etc. Libraire de l'Académie Royale de médicine, Paris

66. Ross J, Goldmann JK (1971) Effect of streptozotocin-induced diabetes on kidney weight and compensatory hypertrophy in the rat. Endocrinology. 88: 1079-1082

67. Mogensen CE, Andersen MJF (1973) Increased kidney size and glomerular filtration rate in early juvenile diabetes. Diabetes 22: 706-712

68. Mogensen CE, Andersen MJF (1975) Increased kidney size and glomerular filtration rate in untreated juvenile diabetics. Normalization by insulin treatment. Diabetologia 11: 221-224

69. Baumgartl HJ, Banholzer P, Sigl G, Haslbeck M, Standl E (1998) On the prognosis of IDDM patients with large kidneys. The role of large kidneys for the development of diabetic nephropathy. Nephrol Dial Transplant 13: 630-634

70. Hostetter TH, Rennke HG, Brenner BM (1982) The case for intrarenal hypertension in the initiation and progression of diabetic and other glomerulopathies. Am J Med 72: 375-380

71. Rudberg S, Persson B, Dahlquist G (1992) Increased glomerular filtration rate as a predictor of diabetic nephropathy - An 8-year prospective study. Kidney Int 41: 822-828

72. Mogensen CE (1971) Kidney function and glomerular permeability in early juvenile diabetes. Scand J Clin Lab Invest 28: 79-90

73. Mogensen CE, Christensen CK (1984) Predicting diabetic nephropathy in insulin-dependent patients. N Engl J Med 311: 89-93 
74. Mau Pedersen M, Christiansen JS, Pedersen EB, Mogensen CE (1992) Determinants of intra-individual variation in kidney function in normoalbuminuric insulin-dependent diabetic patients: importance of atrial natriuretic peptide and glycaemic control. Clinical Science 83: 445-451

75. Eiskjær H, Mogensen CE, Schmitz A, Pedersen EB (1991) Enhanced urinary excretion of albumin and $\beta_{2}$ microglobulin in essential hypertension induced by atrial natriuretic peptide. Scand J Clin Lab Invest 51: 359-366

76. Lutterman JA, Vervoort G, Wetzels JFM, Berden JHM, Smits P (1998) Increased albuminuric response to infusion of atrial natriuretic peptide in normoalbuminuric Type I diabetes. Diabetologia 41:A39

77. Mau Pedersern M (1998) Early renal hyperfunction and hypertrophy in IDDM patients including comments on early intervention. In: Mogensen CE (ed) The Kidney and Hypertension in Diabetes Mellitus. Kluwer Academic Publ., Boston, Dordrecht, London, pp 383-392

78. Østerby R, Gall M-A, Schmitz A, Nielsen FS, Nyberg G, Parving H-H (1993) Glomerular structure and function in proteinuric type 2 (non-insulin-dependent) diabetic patients. Diabetologia 36: 1064-1070

79. Mogensen CE (1998) Combined high blood pressure and glucose in type 2 diabetes: double jeopardy (editorial). BMJ 317: 693-694

80. American Diabetes Association (1999) Implications of the United Kingdom Prospective Diabetes study Diabetes Care 22, Suppl. 1 S27-S31

81. Borch-Johnsen K, Nissen H, Henriksen E, Kreiner S, Salling N, Deckert T, Nerup J (1987) The natural history of insulin-dependent diabetes mellitus in Denmark: 1. Longterm survival with and without late diabetic complications. Diabet Med 4: 201-210

82. Siperstein MD, Unger RH, Madison LL (1968) Studies of muscle Capillary Basement Membranes in Normal Subjects, Diabetic and Prediabetic Patients. J Clin Invest 47: 1973-1999

83. Deckert T, Poulsen JE (1981) Diabetic nephropathy: fault or destiny? Diabetologia 21: 178-183

84. Pirart J (1978) Diabetes mellitus and its degenerative complications: a prospective study of 4,400 patients observed between 1947 and 1973. Diabetes Care 1: 168-188

85. Feldt-Rasmussen B, Mathiesen ER, Jensen T, Lauritzen T, Deckert T (1991) Effect of improved metabolic control loss of kidney function in type 1 (insulin-dependent) diabetic patients: an update of the Steno studies. Diabetologia 34: $164-170$

86. Tarnow L, Gluud C, Parving H-H (1998) Diabetic nephropathy and the insertion/deletion polymorphism of the angiotensin-converting enzyme gene. Nephrology Dialysis Transplantation 13: 410-412

87. Alaveras EAG, Thomas SM, Sagriotis A, Viberti GC (1997) Promotors of progression of diabetic nephropathy: the relative roles of blood glucose and blood pressure control. Nephrology Dialysis Transplantation 12: 71-74

88. Björck S, Blohmé G, Sylvén C, Mulec H (1997) Deletion insertion polymorphism of the angiotensin converting enzyme gene and progression of diabetic nephropathy. Nephrology Dialysis Transplantation 12: 67-70

89. Fagerudd JA, Tarnow L, Jacobsen P et al. (1998) Predisposition to essential hypertension and development of diabetic nephropathy in IDDM patients. Diabetes 47: 439-444

90. Rudberg S, Stattin E-L, Dahlquist G (1998) Familial and perinatal risk factors for micro- and macroalbuminuria in young IDDM patients. Diabetes 47: 1121-1126

91. Cowie CC, Port F, Wolfe R, Savage PJ, Moll PP, Hawthorne VM (1989) Disparities in incidence of diabetic end-stage re- nal disease according to race and type of diabetes. N Engl J Med 321: 1074-1079

92. Freedman BI, Soucie JM, McClellan WM (1997) Family history of end-stage renal disease among incident dialysis patients. J Am Soc Nephrol 8: 1942-1945

93. Borch-Johnsen K, Nørgaard K, Hommel E, Mathiesen ER, Jensen JS, Deckert T, Parving H-H (1992) Is diabetic nephropathy an inherited complication? Kidney Int 41: 719-722

94. Barker DJP (1994) Mothers, babies and diseases in later life. BMJ Publishing Group

95. Nyengaard JR, Bendtsen TF, Mogensen CE (1996) Low birth weight - is it associated with few and small glomeruli in normal persons and NIDDM (non-insulin-dependent diabetes mellitus) patients? Diabetologia 39: 1634-1637

96. Nyengaard JR, Vestbo E (1998) The concept of low birth weight and renal disease. In: Mogensen CE (ed) The kidney and hypertension in diabetes mellitus, 4th ed., Kluwer Academic Publ., Boston, Dordrecht, London, pp 123-130

97. Ravelli ACJ, van der Meulen JHP, Michels RPJ, Osmond C, Barker DJP, Hales CN, Bleker OP (1998) Glucose tolerance in adults after prenatal exposure to famine. Lancet 351: 173-177

98. Yudkin JS, Stanner S (1998) Prenatal exposure to famine and health in later life. Lancet 351: 1361-1362

99. Berggård I, Risinger G (1961) Quantitative immunochemical determination of albumin in normal human urine. Acta Soc Med Upsaliensis 66: 217-222

100. Keen H, Chlouverakis C, Fuller J, Jarret RS (1969) The concomitants of raised blood sugar: studies in newly-detected hyperglycaemics. II. Urinary albumin excretion, blood pressure and their relation to blood sugar levels. Guy's Hospital Reports 118: 247-254

101. Bigazzi R, Bianchi S, Baldari D, Campese VM (1998) Microalbuminuria predicts cardiovascular events and renal insufficiency in patients with essential hypertension. J Hypertens 16: 1325-1333

102. Poulsen PL, Mogensen CE (1995) Evaluation of a new semiquantitative stix for microalbuminuria. Diabetes Care 18: 732-733

103. Mogensen CE, Viberti GC, Peheim E et al. (1997) Multicenter evaluation of the Micral-test II test strip, an immunologic rapid test for the detection of microalbuminuria. Diabetes Care 20: 1642-1646

104. Poulsen PL, Mogensen CE (1998) Clinical evaluation of a test for immediate and quantitative determination of urinary albumin-to-creatinine ratio. Diabetes Care 21: 97-98

105. Parving H-H, Oxenbøll B, Svendsen PA, Christiansen JS, Andersen AR (1982) Early detection of patients at risk of developing diabetic nephropathy. A prospective study of urinary albumin excretion. Acta Endocrinol (Copenhagen) 100: $550-555$

106. Viberti GC, Hill RD, Jarret RJ, Argyropoulos A, Mahmud U, Keen H (1982) Microalbuminuria as a predictor of clinical nephropathy in insulin-dependent diabetes mellitus. Lancet I:1430-1432

107. Mau Pedersen M, Christensen CK and Mogensen CE (1992) Long-term (18 year) prognosis for normo- and microalbuminuric type 1 (insulin-dependent) diabetic patients. Diabetologia 35:A60 (Abstract)

108. Messent JWC, Elliott TG, Hill RD, Jarrett RJ, Keen H, Viberti GC (1992) Prognostic significance of microalbuminuria in insulin-dependent diabetes mellitus: A twenty-three year follow-up study. Kidney International 41: 836-839

109. Rossing P, Hougaard P, Borch-Johnsen K, Parving $\mathrm{H}-\mathrm{H}$ (1996) Risk factors for mortality in IDDM patients, a 10 years observational follow up study. BMJ 313: 779-784

110. Forsblom CM, Groop P-H, Ekstrand A, Groop LC (1992) Predictive value of microalbuminuria in patients with insu- 
lin-dependent diabetes of long duration. BMJ 305: 1051-1053

111. Mogensen CE (1983) Microalbuminuria in maturity onset, primarily type 2 (non-insulin-dependent) diabetes, predicts clinical proteinuria and early mortality. Diabetologia 26: 181 (Abstract)

112. Mogensen CE (1984) Microalbuminuria predicts clinical proteinuria and early mortality in maturity-onset diabetes. N Engl J Med 310: 356-360

113. Dinneen S, Gerstein HC (1997) The association of microalbuminuria and mortality in non-insulin-dependent diabetes mellitus. A systematic overview of the literature. Arch Intern Med 157: 1413-1418

114. Tanaka Y, Atsumi Y, Matsuoka K, Onuma T, Tohjima T, Kawamori R (1998) Role of glycemic control and blood pressure in the development and progression of nephropathy in elderly Japanese NIDDM Patients. Diabetes Care 21: $116-120$

115. Forsblom CM, Groop P-H, Ekstrand A et al. (1998) Predictors of progression from normoalbuminuria to microalbuminuria in NIDDM. Diabetes Care 21: 1932-1938

116. Schmitz A (1997) Microalbuminuria, blood pressure, metabolic control, and renal involvement. Longitudinal studies in white non-insulin-dependent diabetic patients. American Journal of Hypertension 10: 189S-197S

117. Schmitz A, Væth M, Mogensen CE (1994) Systolic blood pressure relates to the rate of progression of albuminuria in NIDDM. Diabetologia 37: 1251-1258

118. Nielsen S, Schmitz O, Ørskov H, Mogensen CE (1995) Similar insulin sensitivity in NIDDM patients with normo- and microalbuminuria. Diabetes Care 18: 834-842

119. Nielsen S, Schmitz O, Møller N, Pørksen N, Klausen IC, Alberti KGMM, Mogensen CE (1993) Renal function and insulin sensitivity during simvastatin treatment in Type 2 (non-insulin-dependent) diabetic patients with microalbuminuria. Diabetologia 36: 1079-1086

120. Nielsen S, Schmitz A, Rehling M, Mogensen CE (1997) The clinical course of renal function in NIDDM patients with normo- and microalbuminuria. J Intern Med 241: 133-141

121. Nielsen S, Schmitz A, Rehling M, Mogensen CE (1993) Systolic blood pressure determines the rate of decline of glomerular filtration rate in Type 2 (non-insulin-dependent) diabetes mellitus. Diabetes Care 16: 1427-1432

122. Nielsen S, Schmitz A, Poulsen PL, Hansen KW, Mogensen CE (1995) Albuminuria and 24-h ambulatory blood pressure in normoalbuminuric and microalbuminuric NIDDM patients: a longitudinal study. Diabetes Care 18: 1434-1441

123. Nielsen S, Schmitz A, Derkx FHM, Mogensen CE (1995) Prorenin and renal function in NIDDM patients with normo- and microalbuminuria. $\mathrm{J}$ Intern Med 238: 499-505

124. Nielsen S, Schmitz A, Bacher T, Rehling M, Ingerslev J, Mogensen CE (1999) Effects of short-term treatment with low-molecular weight heparin in NIDDM patients with and without abnormal albuminuria. Dissociation of albuminuria and transcapillary escape rate of albumin as markers of microvascular dysfuntion. Diabetologia (in press)

125. Nielsen S, Schmitz A, Knudsen RE, Dollerup J, Mogensen CE (1994) Enalapril versus bendroflumethiazide in type 2 diabetes complicated by hypertension. Q J Med 87: 747-754

126. Fioretto P, Stehouwer CDA, Mauer M et al. (1998) Heterogeneous nature of microalbuminuria in NIDDM: Studies of endothelial function and renal structure. Diabetologia 41: 233-236

127. Inomata S, Osawa Y, Itoh M (1987) Analysis of urinary proteins in diabetes mellitus - with reference to the relationship between microalbuminuria and diabetic renal lesions. J Jpn Diabetes Soc 30: 429-436
128. UKPDS 33 (1998) An intensive blood glucose control policy with sulphonylureas or insulin reduces the risk of diabetic complications in patients with Type 2 diabetes. Lancet 352: $837-853$

129. UKPDS 34 (1998) Effect of an intensive blood glucose control policy with metformin on complications in Type 2 diabetic patients. Lancet 352: 854-865

130. Turner R, Holman R, Stratton I et al. for United Kingdom Prospective Diabetes Study Group (1998) Tight blood pressure control and risk of macrovascular and microvascular complications in type 2 diabetes: United Kingdom prospective diabetes study 38 . BMJ 317: 703-713

131. Holman R, Turner R, Stratton I et al. for United Kingdom Prospective Diabetes Study Group (1998). Efficacy of atenolol and captopril in reducing risk of macrovascular and microvascular complications in type 2 diabetes: United Kingdom prospective diabetes study 39. BMJ 317: 713-720

132. Tatti P, Pahor M, Byington RP, Di Mauro P, Guarisco RG, Strollo G, Strollo F (1998) Outcome results of the fosinopril versus amlodipine cardiovascular events randomized trials (FACET) in patients with hypertension and NIDDM. Diabetes Care 21: 597-603

133. Tuomilehto J, Rastenyte D, Thisj L, Staessen J (1998) Reduction of mortality and cardiovascular events in older diabetic patients with isolated systolic hypertension in Europe treated with nitrendipine-based antihypertensive therapy (Syst-Eur-Trial). Diabetes 47:A54 (Abstract)

134. Hansson L, Zanchetti A, Carruthers SG et al. for the HOT Study Group (1998). Effects of intensive blood-pressure lowering and low-dose aspirin in patients with hypertension: principal results of the Hypertension Optimal Treatment (HOT) randomised trial. Lancet 351: 1755-1762

135. Estacio RO, Jeffers BW, Hiatt RA, Biggerstaff SL, Gifford N, Schrier RW (1998) The effect of nisoldipine as compared with enalapril on cardiovascular outcomes in patients with non-insulin-dependent diabetes and hypertension. N Engl J Med 338: 645-652

136. Hansson L, Lindholm LH, Niskanen L et al. Principal results of the Captopril Prevention Project (CAPPP). Effect of angiotensin converting enzyme inhibition compared with conventional therapy on cardiovascular morbidity and mortality in hypertension. Lancet (in press)

137. Curb JD, Pressel SL, Cutler JA et al. (1996) Effect of diuretic-based antihypertensive treatment on cardiovascular disease risk in older diabetic patients with isolated systolic hypertension. Systolic Hypertension in the Elderly Program Cooperative Research Group. JAMA 276: 1886-1892

138. Malmberg K, Rydén L, Wedel H (1998) Calcium antagonists, appropriate therapy for diabetic patients with hypertension? Eur Heart J 19: 1269-1272

139. Pyorälä K, Olsson AG, Pedersen TR et al. (1997) Cholesterol lowering with simvastatin improves prognosis of diabetic patients with coronary heart disease. Diabetes Care 20: $614-620$

140. Kylin E (1923) Studien über das Hypertonie-Hyperglykämie-Hyperurikaemie Syndrom. Zentralblatt für Innere Medizin 7: 105-112

141. Himsworth HP (1939) Mechanisms of diabetes mellitus (Goulstonian Lecture). Lancet 2: 1-6, 65-68, 118-122, 171-175

142. Vague J (1949) Le diabète de la femme androide. Presse Méd. Paris 57: 835-837

143. Vague J (1952) Conditions étiologiques et évolution générale du diabète. Marseille Méd 89: 427-444

144. Avogaro P, Creapaldi G (1965) Essential hypertension, hyperlipemia, obesity and diabetes. European Association for the Study of Diabetes. Diabetologia 1: 137 (Abstract) 
145. Jarrett RJ (1992) In defence of insulin: a critique of syndrome X. Lancet 340: 469-471

146. Karlefors T (1966) Circulatory studies during exercise with particular reference to diabetes. Acta Med Scand 180 [Suppl 449]:1-87

147. Christensen CK (1991) The pre-proteinuric phase of diabetic nephropathy. Dan Med Bull 38: 145-159

148. Vittinghus E, Mogensen CE (1981) Albumin excretion and renal hemodynamic response to physical exercise in normal and diabetic man. Scand J Clin Lab Invest 41: 627-632

149. Vittinghus E, Mogensen CE (1982) Graded exercise and protein excretion in diabetic man and the effect of insulin treatment. Kidney Int 21: 725-729

150. Mogensen CE, Vittinghus E (1975) Urinary albumin excretion during exercise in juvenile diabetes. A provocative test for early abnormalities. Scand J Clin Lab Invest 35: 295-300

151. Mogensen CE, Sølling K (1977) Studies on renal tubular protein reabsorption: Partial and near complete inhibition by certain amino acids. Scand J Clin Lab Invest 37: 477-486

152. Mogensen CE, Vittinghus E, Sølling K (1975) Increased urinary albumin, light chain, and beta-2-microglobulin excretion after intravenous arginine administration in normal man. Lancet II:581-583

153. Mogensen CE, Christensen NJ, Gundersen HJG (1978) The acute effect of insulin on renal haemodynamics and protein excretion in diabetics. Diabetologia 15: 153-157

154. Parving H-H, Christiansen JS, Noer I, Tronier B, Mogensen CE (1980) The effect of glucagon infusion on kidney function in short-term insulin-dependent juvenile diabetics. Diabetologia 19: 350-354

155. Parving H-H, Noer I, Kehlet H, Mogensen CE. Svendsen PAa, Heding L (1977) The effect of short-term glucogen infusion on kidney function in normal man. Diabetologia 13: 323-325

156. Parving H-H, Noer I, Mogensen CE, Svendsen PA (1978) Kidney function in normal man during short-term growth hormone infusion. Acta Endocrinol (Copenhagen) 89: 796-800

157. Mogensen CE, Vittinghus E, Sølling K (1979) Abnormal albumin excretion after two provocative renal test in diabetes: Physical exercise and lysine injection. Kidney Int 16: 385-393

158. Hinman AT, Engel BT, Bickford AF (1962) Portable blood pressure recorder. Accuracy and preliminary use in evalutating intradaily variations in pressure. Am Heart J 63: $663-668$

159. Richardson DW, Honour AJ, Fenton GW, Stott FH and Pickering GW (1964) Variation in arterial pressure throughout the day and night. Clin Sci 26: 445-460

160. Rubler S, Abenavoli T, Greenblatt HA, Dixon JF, Cieslik CJ (1982) Ambulatory blood pressure monitoring in diabetic males: A method for detecting blood pressure elevations undisclosed by conventional methods. Clin Cardiol 5: 447-454

161. Hansen KW, Christensen CK, Andersen PH, Mau Pedersen M, Christiansen JS, Mogensen CE (1992) Ambulatory blood pressure in microalbuminuric type 1 diabetic patients. Kidney Int 41: 847-854

162. Hansen KW, Klein F, Christensen PD et al. (1994) Effects of captopril on ambulatory blood pressure, renal and cardiac function in microalbuminuric type 1 diabetic patients. Diabetes Metab 20: 485-493

163. Hansen KW, Mau Pedersen M, Christensen CK, Christiansen JS, Mogensen CE (1992) Normoalbuminuria ensures no reduction of renal function in Type 1 (insulin-dependent) diabetic patients. J Intern Med 232: 161-167
164. Hansen KW, Mau Pedersen M, Christiansen JS, Mogensen CE (1993) Acute renal effects of angiotensin converting enzyme inhibition in microalbuminuric type 1 diabetic patients. Acta Diabetol 30: 149-153

165. Hansen KW, Mau Pedersen M, Christiansen JS, Mogensen CE (1993) Diurnal blood pressure variations in normoalbuminuric type 1 diabetic patients. J Intern Med 234: 175-180

166. Hansen KW, Mau Pedersen M, Christiansen JS, Mogensen CE (1994) Night blood pressure and cigarette smoking; disparate association in healthy subjects and diabetic patients. Blood Pressure 3: 381-388

167. Hansen KW, Mau Pedersen M, Marshall SM, Christiansen JS, Mogensen CE (1992) Circadian variation of blood pressure in patients with diabetic nephropathy. Diabetologia 35: 1074-1079

168. Hansen KW, Poulsen PL, Christiansen JS, Mogensen CE (1995) Determinants of 24-h blood pressure in IDDM patients. Diabetes Care 18: 529-535

169. Hansen KW, Poulsen PL, Mogensen CE (1994) Ambulatory blood pressure and abnormal albuminuria in type 1 diabetic patients. Kidney Int 45 [Suppl 45]:S134-S140

170. Hansen KW, Sørensen K, Christensen PD, Pedersen EB, Christiansen JS, Mogensen CE (1995) Night blood pressure: Relation to organ lesions in microalbuminuric type 1 diabetic patients. Diabet Med 12: 42-45

171. Poulsen PL, Hansen KW, Mogensen CE (1994) Ambulatory blood pressure in the transition from normo- to microalbuminuria. A longitudinal study in IDDM patients. Diabetes 43: 1248-1253

172. Poulsen PL, Ebbehøj E, Hansen KW, Mogensen CE (1997) 24-h blood pressure and autonomic function is related to albumin excretion within the normoalbuminuric range in IDDM patients. Diabetologia 40: 718-725

173. Poulsen PL, Bek T, Ebbehøj E, Hansen KW, Mogensen CE (1998) 24-h ambulatory blood pressure and retinopathy in normoalbuminuric IDDM patients. Diabetologia 41: $105-110$

174. Poulsen PL, Juhl B, Ebbehøj E, Klein F, Christiansen C, Mogensen CE (1997) Elevated ambulatory blood pressure in microalbuminuric IDDM patients is inversely associated with renal plasma flow. A compensatory mechanism? Diabetes Care 20: 429-432

175. Hansen KW, Poulsen PL, Ebbehøj E (1998) Blood pressure elevation in diabetes: the results from 24-h ambulatory blood pressure recordings. In: Mogensen CE (ed) The Kidney and hypertension in diabetes mellitus, 4th ed., Kluwer Academic Publ., Boston, Dordrecht, London, pp 335-356

176. Pinkney JH, Denver AE, Yudkin JS (1997) Ambulatory blood pressure monitoring in diabetes: An analysis of its potential in clinical practice. Cardiovascular Risk Factors 7: $175-183$

177. Poulsen PL, Ebbehøj E, Mogensen CE (1998) Early ACEintervention in microalbuminuria: $24 \mathrm{~h} \mathrm{BP}$, renal function, and exercise changes. Nephrol Dial Transplant 13: 1056-1079

178. Poulsen PL, Ebbehøj E, Hansen KW, Mogensen CE (1998) Effects of smoking on 24-h ambulatory blood pressure and autonomic function in normoalbuminuric insulin-dependent diabetes mellitus patients. Am J Hypertens 11: 1093-1099

179. Azar ST, Birbari A (1998) Nocturnal blood pressure elevation in patients with type 1 diabetes receiving intensive insulin therapy compared with that in patients receiving conventional insulin therapy. J Clin Endocrinol Metab 83: 3190-3192

180. Wallenius G (1954) Renal clearance of dextran as a measure of glomerular permeability. Acta Soc Med Upsaliensis [Suppl 4] 
181. Lins H, Jahnke K, Scholtan W (1959) Über die Permeabilität makromolekularer Stoffe. In: Oberdisse K, Jahnke K (eds) Die Niere bei diabetischen und anderen Nephropathien in Diabetes Mellitus. Proceedings of the III. Congress of the International Diabetes Federation. Georg Thieme Verlag, Stuttgart, pp 203-206

182. Lambert PP, Gassée JP, Askenasi R (1968) La perméabilité $\mathrm{du}$ rein aux macromolécules physiopathologie de la protéinurie. In: Lambert PP (ed) Acquisitions récentes de physiopathologie rénale. Editions Desoer S. A., Liège, Belgique, pp 181-214

183. Deckert T, Kofoed-Enevoldsen A, Vidal P, Nørgaard K, Andreasen HB, Feldt-Rasmussen B (1993) Size- and charge selectivity of glomerular filtration in type 1 (insulin-dependent) diabetic patients with and without albuminuria. Diabetologia 36: 244-251

184. Myers BD, Nelson RG, Williams GW et al. (1991) Glomerular function in Pima Indians with noninsulin-dependent diabetes mellitus of recent onset. J Clin Invest 88: 524-530

185. Morelli E, Loon N, Meyer T, Peters W, Myers BD (1990) Effects of converting-enzyme inhibition on barrier function in diabetic glomerulopathy. Diabetes 39: 76-82

186. Gaster B, Hirsch IB (1998) The effects of improved glycemic control on complications in type 2 diabetes. Archives of Internal Medicine 158: 134-140

187. Krolewski AS, Laffel LMB, Krolewski M, Quinn M, Warram JH (1995) Glycosylated hemoglobin and the risk of microalbuminuria in patients with insulin-dependent diabetes mellitus. N Engl J Med 332: 1251-1255

188. Microalbuminuria Collaborative Study Group, UK (1995) Intensive therapy and progression to clinical albuminuria in patients with insulin dependent diabetes mellitus and microalbuminuria. BMJ 311: 973-977

189. Christensen CK, Mogensen CE (1985) The course of incipient diabetic nephropathy: Studies of albumin excretion and blood pressure. Diabetic Medicine 2: 97-102

190. Christensen CK, Mogensen CE (1985) Effect of antihypertensive treatment on progression of disease in incipient diabetic nephropathy. Hypertension 7:II-109-II-113

191. Christensen CK, Mogensen CE (1987) Antihypertensive treatment: long-term reversal of progression of albuminuria in incipient diabetic nephropathy. A longitudinal study of renal function. J Diabetes Complications 1: 45-52

192. Mau Pedersen M, Christensen CK, Hansen KW, Christiansen JS, Mogensen CE (1991) ACE-inhibition and renoprotection in early diabetic nephropathy. Response to enalapril acutely and in long-term combination wtih conventional antihypertensive treatment. Clin Invest Med 14: 642-651

193. Mau Pedersen M, Hansen KW, Schmitz A, Sørensen K, Christensen CK, Mogensen CE (1992) Effects of ACE inhibition supplementary to beta blockers and diuretics in early diabetic nephropathy. Kidney Int 41: 883-890

194. Mogensen CE, Pedersen M.M, Ebbehøj E, Poulsen PL, Schmitz A (1997) Combination therapy in hypertension-associated diabetic renal disease. International Journal of Clinical Practice [Suppl] 90: 52-58

195. Marre M, Chatellier G, Leblanc H, Guyenne T-T, Ménard J, Passa PH (1988) Prevention of diabetic nephropathy with Enalapril in normotensive diabetics with microalbuminuria. BMJ 297: 1092-1095

196. Mathiesen ER, Hommel E, Giese J, Parving H-H (1991) Efficacy of captopril in postponing nephropathy in normotensive insulin-dependent diabetic patients with microalbuminuria. BMJ 303: 81-87

197. Mathiesen ER, Hommel E, Hansen HP, Parving H-H (1998) Preservation of normal GFR in type 1 diabetic patients with microalbuminuria under long-term (8 years) ACE inhibition. Nephrol Dial Transplant 13: 1062
198. Melbourne Diabetic Nephropathy Study Group (1991) Comparison between perindopril and nifedipine in hypertensive and normotensive diabetic patients with microalbuminuria. BMJ 302: 210-216

199. Barnes DJ, Cooper M, Gans DJ, Laffel L, Mogensen CE, Viberti GC (1996) Microalbuminuria Captopril Study Group. Captopril reduces the risk of nephropathy in insulin-dependent diabetic patients with microalbuminuria. Diabetologia 39: 587-593

200. Ravid M, Lang R, Rachmani R, Lishner M (1996) Longterm renoprotective effect of angiotensin-converting enzyme inhibition in non-insulin-dependent diabetes mellitus. A 7-year follow-up study. Archives of Internal Medicine 156: 286-289

201. Ravid M, Brosh D, Levi Z, Bar-Dayan Y, Ravid D, Rachmani R (1998) Use of enalapril to attenuate decline in renal function in normotensive patients with type 2 diabetes mellitus. A randomized controlled trial. Ann Intern Med 128: 982-988

202. Viberti GC, Mogensen CE, Groop L, Pauls JF for the European Microalbuminuria Captopril Study Group (1994) Effect of captopril on progression to clinical proteinuria in patients with insulin-dependent diabetes mellitus and microalbuminuria. JAMA 271: 275-279

203. Charturvedi N (1998) When should ACE inhibitors be used in IDDM patients? A combined analysis of clinical trials. Diabetologia 41:A5 (Abstract)

204. Bennett PH, Haffner S, Kasiske BL et al. (1995) Screening and management of microalbuminuria in patients with diabetes mellitus - recommendations to the scientific advisory board of the national kidney foundation from an ad hoc committee of the council on diabetes mellitus of the national kidney foundation. Am J Kidney Dis 25: 107-112

205. Mogensen CE (1971) Glomerular filtration rate and renal plasma flow in short-term and long-term juvenile diabetes. Scand J Clin Lab Invest 28: 91-100

206. Mogensen CE (1971) Maximum tubular reabsorption capacity for glucose and renal hemodynamics during rapid hypertonic glucose infusion in normal and diabetic man. Scand J Clin Lab Invest 28: 101-109

207. Mogensen CE (1976) Progression of nephropathy in longterm diabetes with proteinuria and effect of initial hypertensive treatment. Scand J Clin Lab Invest 36: 383-388

208. Mogensen CE (1976) High blood pressure as a factor in the progression of diabetic nephropathy. Acta Med Scand [Suppl 602]:29-32

209. Mogensen CE, Hansen KW, Mau Pedersen M, Christensen CK (1991) Renal factors influencing blood pressure threshold and choice of treatment for hypertension in IDDM. Diabetes Care 14[Suppl 4]:13-26

210. Mogensen CE (1997) How to protect the kidney in diabetic patients: with special reference to IDDM. Diabetes 46 [Suppl 2]S104-S111

211. Mogensen CE (1982) Long-term antihypertensive treatment inhibiting progression of diabetic nephropathy. BMJ 285: 685-688

212. Parving H-H, Smidt UM, Andersen AR, Svendsen PAA (1983) Early aggressive antihypertensive treatment reduces rate of decline in kidney function in diabetic nephropathy. Lancet I:1175-1179

213. Parving H-H, Andersen AR, Schmidt UM, Hommel E, Mathiesen ER, Svendsen PAA (1987) Effect of antihypertensive treatment on kidney function in diabetic nephropathy. BMJ 294: 1443-1447

214. Parving H-H, Jacobsen P, Rossing K, Smidt UM, Hommel E, Rossing P (1996) Benefits of long-term antihypertensive treatment on prognosis in diabetic nephropathy. Kidney Int 49: 1778-1782 
215. Parving H-H, Hommel E (1989) Prognosis in diabetic nephropathy. BMJ 299: 230-233

216. Mathiesen ER, Borch-Johnsen K, Jensen DV, Deckert T (1989) Improved survival in patients with diabetic nephropathy. Diabetologia 32: 884-886

217. Björck S, Mulec H, Johnsen SA, Nordén G, Aurell M (1992) Renal protective effect of enalapril in diabetic nephropathy. BMJ 304: 339-343

218. Lewis E, Hunsicker L, Bain R, Rhode R (1993) The effect of angiotensin-converting enzyme inhibition on diabetic nephropathy. N Engl J Med 329: 1456-1462

219. Weir MR, Dworkin LD (1998) Antihypertensive drugs, dietary salt, and renal protection: How low should you go and with which therapy? Am J Kidney Dis 32(1):1-22

220. de Courten M, Böhlen L, Weidmann P (1994) Antihypertensive treatment of diabetic and nondiabetic renal disease: drug-specific differences in reducing proteinuria. J Hypertens 12 [Suppl 3]:S112

221. Ruggenenti P, Perna A, Gherardi G, Gaspari F, Benini R, Remuzzi G on behalf of the Gruppo Italiano di Studi Epidemiologici in Nefrologia (GISEN) (1998) Renal function and requirement for dialysis in chronic nephropathy patients on long-term ramipril: REIN follow-up trial. Lancet 352: 1252-1256

222. Nyberg G, Blohmé G, Nordén G (1987) Impact of metabolic control in progression of clinical diabetic nephropathy. Diabetologia 30: 82-86

223. Pickup JC, Keen H, Parsons JA, Alberti KGMM (1978) Continuous subcutaneous insulin infusion: an approach to achieving normoglycaemia. BMJ 1: 204-207

224. Christensen CK, Christiansen JS, Christensen T, Hermansen K, Mogensen CE (1986) The effect of six months continuous subcutaneous insulin infusion on kidney function and size in insulin-dependent diabetics. Diabetic Medicine 3: $29-32$

225. Møller A, Rasmussen L, Ledet T, Christiansen JS, Christensen CK, Mogensen CE, Hermansen K (1986) Lipoprotein changes during CSII treatment in IDDM patients Scand J Clin Lab Invest 46: 471-475

226. Thuesen L, Christiansen JS, Sørensen KE et al. (1986) Exercise capacity and cardiac function in type 1 diabetic patients treated with continuous subcutaneous insulin infusion. A controlled study. Scand J Clin Lab Invest 46: 779-784

227. Hermansen K, Møller A, Christensen CK et al. (1987) Diurnal plasma profiles of metabolite and hormone concentration in insulin-dependent diabetic patients during conventional insulin treatment and continuous subcutaneous insulin infusion. A controlled study. Acta Endocrinol (Copenhagen) 114: 433-439

228. Mogensen CE (1988) Therapeutic inverventions in nephropathy of IDDM. Diabetes Care 11 [Suppl 1]:10-15

229. Jakobsen J, Christiansen JS, Christensen CK, Hermansen K, Schmitz A, Mogensen CE (1988) Autonomic and somatosensory nerve function after two years of continuous subcutaneous insulin infusion in type 1 diabetes. Diabetes 37: $452-455$

230. Hermansen K, Schmitz O, Boye N, Christensen CK, Christiansen JS, Alberti KGMM, Ørskov H, Mogensen CE (1988) Glucagon responses to intravenous arginine and oral glucose in insulin-dependent diabetic patients during six months conventional or continous subcutaneous insulin infusion. Metabolism 37: 640-644

231. Schmitz A, Christiansen JS, Christensen CK, Hermansen K, Mogensen CE (1989) Effect of pump versus pen treatment on glycemic control and kidney-function in longterm uncomplicated insulin-dependent diabetes-mellitus (IDDM). Dan Med Bull 36: 176-178
232. Mogensen CE, Hansen KW (1990) Preventing or postponing renal disease in insulin-dependent diabetes by glycemic and nonglycemic intervention. In: Klinkmann H, Smeby LC (eds) Terminal Renal Failure: Therapeutic Problems, Possibilities, and Potentials. Contrib Nephrol, Karger, Basel 78: 73-101

233. Kelly WD, Lillehei RC, Merkel FK, Idezuki Y, Goetz FC (1967) Allotransplantation of the pancreas and duodenum along with the kidney in diabetic nephropathy. Surgery 61 : 827

234. Dubernard JM, Traeger J, Neyra P, Touraine JL, Tranchant D, Blanc-Brunat N (1978) A new method of preparation of segmental pancreatic grafts for transplantation. Trials in dogs and in man. Surgery 84: 633

235. Sutherland DER, Dunn DL, Goetz FC et al. (1989) A 10year experience with 290 pancreas transplants at a single institution. Ann Surg 210: 274-285

236. Manske CL (1999) Risks and benefits of kidney and pancreas transplantation for diabetic patients. Diabetes Care (in press)

237. Fioretto P, Steffes MW, Sutherland DER, Goetz FC, Mauer M (1998) Reversal of lesions of diabetic nephropathy after pancreas transplantation. N Engl J Med 339: $69-75$

238. Nyberg G, Holdaas H, Brekke IB, Hartmann A, Nordén G, Olausson M, Østerby R (1996) Glomerular ultrastructure in kidneys transplanted simultaneously with a segmental pancreas to patients with type 1 diabetes. Nephrol Dial Transplant 11: 1029-1033

239. Zatz R, Dunn BR, Meyer TW, Anderson S, Rennke HG, Brenner BM (1986) Prevention of diabetic glomerulopathy by pharmacological amelioration of glomerular capillary hypertension. J Clin Invest 77: 1925-1930

240. Williams B, Cooper ME, McNally PG (1998) Antihypertensive treatment in NIDDM with special reference to abnormal albuminuria. Addendum regarding renovascular hypertension and renal artery stenosis (especially NIDDM). In: Mogensen CE (ed) The Kidney and Hypertension in Diabetes Mellitus. Kluwer Academic Publ, Boston, Dordrecht, London, pp 432-434

241. Mogensen CE (1992) Angiotensin converting enzyme inhibitors and diabetic nephropathy. Their effects on proteinuria may be independent of their effects on blood pressure. Editorial. BMJ 304: 327-328

242. Thuesen L, Christiansen JS, Falstie-Jensen N, Christensen CK, Hermansen K, Mogensen CE, Henningsen P (1985) Increased myocardial contractility in short-term Type 1 diabetic patients: an echocardiographic study. Diabetologia 28: 822-826

243. Parving H-H, Viberti GC, Keen H, Christiansen JS, Lassen NA (1983) Haemodynamic factors in the genesis of diabetic microangiopathy. Metabolism 32: 943-949

244. Gall M-A, Borch-Johnsen K, Hougaard P, Nielsen FS, Parving H-H (1995) Albuminuria and poor glycemic control predicts mortality in NIDDM. Diabetes 44: 1303-1309

245. Stanton A (1998) Calcium channel blockers. BMJ 316: 471-473

246. Mogensen CE (1998) Drug treatment for hypertensive patients in special situations: Diabetes and hypertension. Clin Exp Hypertens (in press)

247. Nielsen S, Dollerup J, Nielsen B, Jensen HA, Mogensen CE (1997) Losartan reduces albuminuria in patients with essential hypertension. An enalapril controlled 3 months study. Nephrol Dial Transplant 12: 19-23

248. Nielsen S (1998) Losartan modifies glomerular hyperfiltration and insulin sensitivity in type 1 diabetes. Diabetologia 41[Suppl 1]:A5 (Abstract) 
249. Krolewski AS, Warram JH, Christlieb AR, Busick EJ, Kahn CR (1985) The changing natural history of nephropathy in type I diabetes. Am J Med 78: 785-794

250. (1948) The controlled therapeutic trial [editorial] BMJ 2: 791-792

251. Chalmers I (1998) Unbiased, relevant and reliable assessments in health care. BMJ 317: 1167-1168

252. University Group Diabetes Program (1970) A study of the effects of hypoglycemic agents on vascular complications in patients with adult-onset diabetes. Diabetes 19 [Suppl 2]: 747-830

253. Creutzfeldt W (1994) The discovery of the oral treatment of diabetes mellitus with sulphonylureas. In: Mogensen CE, Standl E (eds) Research methodologies in Human Diabetes, part 1. Walter de Gruyter, Berlin, New York, pp 11-20

254. Peto R, Collins R, Gray R (1995) Large-scale randomized evidence: large, simple trials and overviews of trials. J Clin Epidemiol 48(1): 23-40

255. Thompson SG, Pocock SJ (1991) Can meta-analyses be trusted? Lancet 338: 1127-30

256. Thomson SG (1994) Why sources of heterogeneity in metaanalysis should be investigated. BMJ 309: 1351-1355

257. Feinstein AR (1995) Meta-analysis: statistical alchemy for the 21st century. J Clin Epidemiol 48: 71-79

258. Spitzer WO (1995) The challenge of meta-analysis (Editor's Keynote Address). J Clin Epidemiol 48: 1-4

259. Victor N (1995) The challenge of meta-analysis: Discussion. Indications and contra-indications for meta-analysis. J Clin Epidemiol 48: 5-8

260. Sharp SJ, Thomson SG, Altman DG (1996) The relation between treatment benefit and underlying risk in metaanalysis. BMJ 313: 1550-1551

261. Lelorier J, Geneviève G, Benhaddad A, Lapierre J, Derderian F (1997) Discrepancies between meta-analyses and subsequent large randomized controlled trials. New Engl J Med 337: 536-542

262. WHO-ISH (1975) Effectiveness of treatment of mild hypertension. WHO Geneva CVD/75.5

263. 1999 Guidelines for the management of hypertension: Memorandum from a World Health Organization/International Society of Hypertension Meeting (1998) J Hypertens (in press)

264. The Sixth Report of the Joint National Committee on Prevention, Detection, Evaluation, and Treatment of High Blood Pressure (1997) Arch Intern Med 157: 2413-2446

265. Recommendations et références médicales de l'annees. Diagnostic et traitement de l'hypertension artérielle essentielle de l'adulte de 20 à 80 ans (1998) Journal des Maladies Vasculaires (Paris) 23, 3: 204-231

266. British Hypertension Society Guidelines (1999) (in press)

267. American Diabetes Association (1998) Standards of medical care for patients with diabetes mellitus. Diabetes Care 21:S23-S31

268. American Diabetes Association (1998) Diabetic nephropathy. Diabetes Care 21:S50-S53

269. National High Blood Pressure Education Program Working Group on Hypertension and Renal Disease (1996) 1995 Update of the working group reports on chronic renal failure and renovascular hypertension. Arch Intern Med 156: $1938-1947$

270. Lundbæk K (1953) Long-term diabetes. The clinical picture in diabetes mellitus of 15-25 years' duration with a follow-up of a regional series of cases. Munksgaard, Copenhagen and Lange, Maxwell \& Springer Ltd., London, New York

271. Cooper ME (1998) Pathogenesis, prevention and treatment of diabetic nephropathy. Lancet 352: 213-219
272. Parving H-H (1998) Is antihypertensive treatment the same for NIDDM and IDDM patients? Diabetes Research and Clinical Practice 39 [Suppl]:S43-S47

273. Anitschkow N, Chalatow S (1913) Uber experim. Cholesterinstesotose, Zentralbl. f. alg Pathol u. pathol Anst Bd 24: 379-403

274. Walker JD (1998) Non-glycaemic intervention in diabetic nephropathy: The role of dietary protein intake. In: Mogensen CE (ed) The Kidney and hypertension in diabetes mellitus. Kluwer Academic Publications, Boston, Dordrecht, London, pp 443-453

275. Feldt-Rasmussen B, Hegedüs L, Mathiesen ER, Deckert T (1991). Kidney volume in type 1 (insulin-dependent) diabetic patients with normal or increased urinary albumin excretion: effect of long-term improved metabolic control. Scand J Clin Lab Invest, 51: 31-36

276. Cambier P (1934) Application de la théorie de Rehberg a l'etude clinique des affections rénales et du diabete. Annales Médicine 35: 273-299

277. Fiaschi E, Grassi B, Andres G (1952). La funzione renal nel diabete mellito. Rassegna di Fisiopatologia Clinica \& Terapeutica 24: $373-410$

278. Stadler G, Schmid R, Wolff MV (1960) Funktionelle Mikroangiopathie der Nieren beim behandelten Diabetes mellitus im Kindesalter. Dtsch Med Wochenschr 85: 346

279. Ditzel J, Schwartz M (1967) Abnormally increased glomerular filtration rate in short-term insulin-treated diabetic subjects. Diabetes 16: 264

280. Mogensen CE (1972) Glomerular filtration rate and renal plasma flow in long-term juvenile diabetics without proteinuria. BMJ 4: 257-259

281. Yip WJ, Jones LS, Wiseman JM, Hill C, Viberti GC (1996) Glomerular hyperfiltration in the prediction of nephropathy in IDDM. Diabetes 45: 1729-1733

282. Keen H, Chlouverakis C (1963) An immunoassay method for urinary albumin at low concentrations. Lancet ii: 913

283. Miles DW, Mogensen CE, Gundersen HJG (1970) Radioimmunoassay for urinary albumin using a single antibody. Scand J Clin Lab Invest 26: 5-11

284. Mogensen CE (1971) Urinary albumin excretion in early and long-term juvenile diabetes. Scand J Clin Lab Invest 28: $183-193$

285. Mogensen CE (1995) Management of early nephropathy in diabetic patients. Ann Rev Med 46: 79-93

286. Mogensen CE (1988) Management of diabetic renal involvement and disease. Lancet I:867-870

287. Mogensen CE, Keane WF, Bennett PH et al. (1995) Prevention of diabetic renal disease with special reference to microalbuminuria. Lancet 346: 1080-1084

288. Keen H, Chlouverakis C (1964) Urinary albumin excretion and diabetes mellitus. Lancet ii:1155

289. Mogensen CE, Vestbo E, Poulsen PL et al. (1995) Microalbuminuria and potential confounders. A review and some observations on variability of urinary albumin excretion. Diabetes Care 18: 572-581

290. Mogensen CE, Poulsen PL (1994) Epidemiology of microalbuminuria in diabetes and in the background population. Curr Opin Nephrol Hypertens 3: 248-256

291. Borch-Johnsen K, Wenzel H Viberti GC, Mogensen CE (1993) Is screening and intervention for microalbuminuria worthwhile in patients with insulin dependent diabetes? BMJ 306: 1722-1725

292. Kimmelstiel P, Wilson C (1936) Intercapillary lesions in the glomeruli of the kidney. Am J Pathol 12: 83-95

293. Kimmelstiel P (1959) On Diabetic Glomerulosclerosis. Diabetes Mellitus. Proceedings of the III Kongress of the International Diabetes Federation. Georg Thieme Verlag, Stuttgart, pp 178-184 
294. Gellman DD, Pirani C, Soothill JF, Muehrcke RC, Kark RM (1959) Diabetic nephropathy: a clinical and pathological study based on renal biopsies. Medicine 38: 321

295. Olsen S (1998) Light microscopy of diabetic glomerulopathy: the classic lesion. In: Mogensen CE (ed) The Kidney and hypertension in diabetes mellitus. 217-226. 4th ed., Kluwer Academic Publ., Boston, Dordrecht, London, pp 217-226

296. Olsen S, Mogensen CE (1996) How often is Type II diabetes mellitus complicated with non-diabetic renal disease? A material of renal biopsies and an analysis of the literature. Diabetologia 39: 1638-1645

297. Thomsen CAA (1965) The Kidney in Diabetes Mellitus. A Clinical and Histological Investigation Based on Renal Biopsy Material. Munksgaard, Copenhagen

298. Mauer SM, Steffes MW, Ellis EN, Sutherland DER, Brown DM, Goetz FC (1984) Structural functional relationships in diabetic nephropathy. J Clin Invest 74: 1143-1155

299. Reaven GM (1997) The kidney: An unwilling accomplice in Syndrome X. Am J Kidney Dis 30: 928-931

300. Keiding NR, Root HF, Marble A (1952) Importance of control of diabetes in prevention of vascular complications. JAMA 150: 964-969

301.Wang PH, Lau J, Chalmers TC (1993) Meta-analysis of effects of intensive blood-glucose control on late complications of type 1 diabetes. Lancet 341: 1306-1309

302. Mulec H, Blohmé G, Grände B, Björck S (1998) The effect of metabolic control on rate of decline in renal function in insulin-dependent diabetes mellitus with overt diabetic nephropathy. Nephrol Dial Transplant 13: 651-655

303. Chaturvedi N, Sjolie A-K, Stephenson JM et al. and the EUCLID Study Group (1998) Effect of lisinopril on progression of retinopathy in normotensive people with type 1 diabetes. Lancet 351: 28-31

304. Crepaldi G, Carta Q, Deferrari G et al. and The Italian Microalbuminuria Study Group in IDDM (1998) Effects of lisinopril and nifedipine on the progression to overt albuminuria in IDDM patients with incipient nephropathy and normal blood pressure. Diabetes Care 21: 104-110

305. Cooper M, McNally P (1998) Antihypertensive treatment in NIDDM, with special reference to abnormal albuminuria. In: Mogensen CE (ed) The kidney and hypertension in diabetes mellitus, 4th ed., Kluwer Academic Publ., Boston, Dordrecht, London, pp 419-434

306. Gæde P, Vedel P, Parving H-H, Pedersen O (1998) The Steno Type 2 study: Intensive multifactorial intervention delays the progression of micro- and macroangiopathy in microalbuminuric Type 2 diabetic patients. Diabetologia 41(1): (Abstract 7)

307. Anderson S (1998) Pathogenesis of diabetic glomerulopathy: The role of glomerular hemodynamic factors. In: Mogensen CE (ed) The kidney and hypertension in diabetes mellitus, 4th ed., Kluwer Academic Publ., Boston, Dordrecht, London, pp 297-306

308. Mau Pedersen M, Schmitz A, Pedersen EB, Danielsen H, Christiansen JS (1988) Acute and long-term renal effects of angiotensin converting enzyme inhibition in normoten- sive, normoalbuminuric insulin-dependent diabetic patients. Diabetic Med 5: 562-569

309. Viberti GC, Keen H, Wiseman MJ (1987) Raised arterial pressure in parents of proteinuric insulin-dependent diabetics. BMJ 295: 515-517

310. Doria A, Warram JH, Krolewski AS (1995) Genetic susceptibility to nephropathy in insulin-dependent diabetes: from epidemiology to molecular genetics. Diabetes Metab Rev 11: 287-314

311. Marre M, Bouhanick B (1997) Genetics and diabetic nephropathy. In: Mogensen CE (ed) The Kidney and hypertension in diabetes mellitus, 4th ed., Kluwer Academic Publ., Boston, Dordrecht, London, pp 399-408

312. Mogensen CE (1998) Exercise and the kidney in diabetes. In: The Kidney and hypertension in diabetes mellitus, 4th ed., Kluwer Academic Publ., Boston, Dordrecht, London, pp 191-198

313. Mogensen CE, Schmitz A, Christensen CK (1988) Comparative Renal Pathophysiology Relevant to IDDM and NIDDM Patients. Diabetes 4(5):453-483

314. Tuominen JA, Ebeling P, Koivisto VA (1998) Long-term lisinopril therapy reduces exercise-induced albuminuria in normoalbuminuric normotensive IDDM patients. Diabetes Care 21: 1345-1348

315. Flyvbjerg A, Hill C, Nielsen B, Grønbæk H, Bak M, Christiansen T, Logan A, Ørskov H (1998) The role of growth hormone, insulin-like growth factors, epidermal growth factor and transforming growth factor- $\beta$ in diabetic kidney disease, an update. In: Mogensen CE (ed) The Kidney and hypertension in diabetes mellitus, 4th ed., Kluwer Academic Publ., Boston, Dordrecht, London, pp 307-320

316. Ziyadeh FN, Cheol Han, Mogyorosi A (1998) Transforming growth factor beta and other cytokines in experimental and human diabetic nephropathy. In: Mogensen CE (ed) The Kidney and hypertension in diabetes mellitus, 4th ed., Kluwer Academic Publ., Boston, Dordrecht, London, pp 321-334

317. Koya D, King GL (1998) Protein kinase C in diabetic renal involvement, the perspective of inhibition. In: Mogensen CE (ed) The Kidney and hypertension in diabetes mellitus, 4th ed., Kluwer Academic Publ., Boston, Dordrecht, London, pp 263-268

318. Hollenberg N (1998) ACE-inhibition and angiotensin II receptor blockade, and diabetic nephropathy. In: Mogensen CE (ed) The Kidney and hypertension in diabetes mellitus, 4th ed., Kluwer Academic Publ., Boston, Dordecht, London, pp 393-398

319. Cooper M, Jerums G (1998) Advanced glycation end-products and diabetic renal disease. In: Mogensen CE, The Kidney and hypertension in diabetes mellitus, 4th ed., Kluwer Academic Publ., Boston, Dordrecht, London, pp 257-262

320. Chavers BM, Bilous RW, Ellis EN, Steffes MW, Mauer M (1989) Glomerular lesions and urinary albumin excretion in type I diabetes without overt proteinuria. N Engl J Med 320: $966-970$

321. Fioretto P, Steffes MW, Mauer M (1994) Glomerular structure in nonproteinuric IDDM patients with various levels of albuminuria. Diabetes 43: 1358-1364 